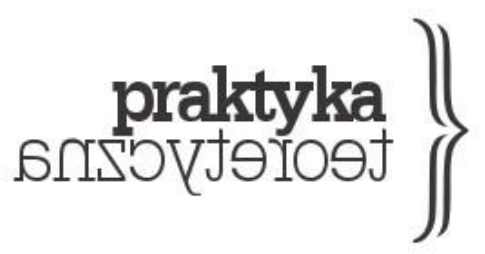

ISSN 2081-8130

DOI: $10.14746 /$ prt.2018.2.3 www.praktykateoretyczna.pl

\title{
KONIEC RELIGII, ŚMIERĆ BOGA I PRZYGODNA WSPÓLNOTA: HEGEL, MALABOU, ŽIŽEK
}

\author{
BARTOSZ WÓJCIK
}

\begin{abstract}
Abstrakt: Artykuł stanowi rozbudowana, opartą na analizie trzech zagadnień interpretację pojęcia końca religii w filozofii G.W.F. Hegla. Po pierwsze, relacji religijnego wyobrażenia i filozofii spekulatywnej - tj. problemu zniesienia religii w filozofii. Po drugie, Heglowskiej wykładni chrześcijaństwa (przedstawionej w Encyklopedii Nauk Filozoficznych i Wykładach z filozofii religii) zogniskowanej wokół koncepcji wcielenia jako kenozy, która jest odczytywana przez pryzmat propozycji interpretacyjnej Catherine Malabou. Po trzecie wreszcie, idei śmierci Chrystusa jako śmierci samego Boga, która stanowi, zdaniem Slavoja Žižka, autentyczny rdzeń chrześcijaństwa dla Hegla. Interpretacja tych problemów prowadzi do następującej konkluzji końca religii u Hegla: uśmiercony Bóg zmartwychwstaje w Duchu Świętym, którego historyczną postacią jest „duch obiektywny” - rewolucyjna wspólnota czynów miłości.
\end{abstract}

Słowa kluczowe: Hegel, dialektyka, religia, Malabou, Žižek, chrześcijaństwo, Bóg, wspólnota. 


\section{1.}

Koniec religii pojawia się w newralgicznym momencie Heglowskiego dzieła i od samego początku rodzi wiele wattpliwości oraz niejasności. Stoi za tym jego związek z dwuznacznym pojednaniem religii i filozofii, które można rozumieć jako wzniesienie stanowiska religijnego na wyższy, spekulatywny poziom, bądź też jako zniesienie, przekroczenie uniwersum religijnego, które ulegnie całkowitej degeneracji w nowej, postreligijnej - filozoficznej epoce. Na oscylacje między tymi oboma biegunami skazuje nas enigmatyczne twierdzenie Hegla:

Filozofia [ma] więc z religia ten sam cel i treść, tyle tylko, że [jej forma] nie [jest] uyobrażenie, lecz myślenie. Dlatego postać religii [jest] niezadowalająca dla bardziej uyjksz̨ałconej świadomości - musi [ona] chcieć poznawać, musi znieść formę religii ale tylko dlatego, żeby usprawiedliwić jej treść (Hegel 1990, 510).

Z kolei we „Wstępie” do Wykładón z filozofii religii czytamy o konieczności pojednania wykształconych we wzajemnym przeciwieństwie „religijnego uczucia” z „naukowym poznaniem" - czyli beztreściowego wznoszenia się do tego, co nieskończone, z poznaniem kauzalnych związków sfery skończoności. Gdy już dochodzi do kulminacyjnego momentu rozdarcia pomiędzy tymi dwoma sferami:

to pojawia się potrzeba uyrónnania, polegającego na tym, że to, co nieskończone przejawia się w tym, co skończone, a to, co skończone w tym, co nieskończone, i żadna z obu stron nie tworzy już odrębnego królestwa. Byłoby to pojednanie głębokiego uczucia religijnego zpoznaniem i inteligencja (Hegel 2006a, 18).

Zniesienie formy religijnej przy zachowaniu czy usprawiedliwieniu jej treści stanowi problem techniczny spekulatywnej filozofii dotyczący rozumienia kategorii Aufhebung (zniesienia) i Versöhnung (pojednania). Na czym miałoby to polegać? Czy Heglowi chodzi o zniesienie religii w ogóle, czy raczej o zniesienie pewnej formy religijnej? Jak w ogóle możliwa jest procedura znoszenia formy bez naruszania treści? A wreszcie, z jakim kończeniemznoszeniem mamy do czynienia w religii - z eschatologicznym „końcem końców” czy raczej z dialektycznym „końcem bez końca”? Czy „koniec religii” byłby dobrym czy złym końcem? Odwołuję się przy tej okazji do podwójności czy dwuznaczności wpisanej w proces dialektyczny, która została już rozpoznana i opracowana przez samego Hegla, a także jego 
licznych komentatorów (np. György'ego Lukácsa1). W powyższym kontekście dobry koniec należałoby pojmować jako moment wyrównawczy i zmierzchowy każdego przebiegu dialektycznego, jako nieustający proces kończenia, który nie zostaje zwieńczony żadnym ostatecznym domknięciem. Natomiast zły koniec byłby absolutnym i punktowym zwinięciem się ruchu pojęciowego, abstrakcyjną śmiercią jako ostatecznym wyzerowaniem² (w gruncie rzeczy opozycja ta jest powtórzeniem Heglowskiej różnicy między „negacją określoną” a „negacją abstrakcyjną). Koniec jako nieosiagalny horyzont umożliwiający mozolną pracę pośredniości i wzajemne odnoszenie do siebie zantagonizowanych momentów (np. filozofii i religii, myślenia i wyobrażenia, czucia i pojmowania itd.), przeciwstawiony jest końcowi momentalnie rozwiązującemu trawiąca dialektyczny system sprzeczność, który obsługują wszystkie metafory skoku, zerwania, spłonięcia, transgresji czy „wystrzału z pistoletu” albo po prostu apokalipsy. Innymi słowy, dobry koniec to „koniec bez końca”, a zły koniec to „koniec końców”.

O podwójności końca u Hegla w związku z dwuznacznościa pojęcia Aufhebung w podobny sposób pisze Slavoj Žižek, gdy zwraca uwage na dwa główne sposoby pojmowania Aufhebung we francuskiej krytyce Hegla - u Gillesa Deleuze'a i Jacquesa Derridy. Ten pierwszy rozumie Aufhebung jako niedoprowadzoną do końca negację, która jest ograniczona i zatrzymana-w-sobie, a przez to zamiast dokonać pełnej anihilacji swojego przedmiotu, zachowuje go i wynosi jego istotowa treść na wyższy, „zapośredniczony” poziom. Tej niepełnej Heglowskiej quasi-negacji Deleuze przeciwstawia Nietzscheańska radykalną negację-destrukcję będąca „oczyszczaniem pola”, czyli otwieraniem przestrzeni

1 Lukács pisał o fundamentalnej różnicy pomiędzy znoszeniem (Aufheben) i samym byciem-zniesionym (Aufgebobensein) (Lukács 1980, 493), którą można sprowadzić do różnicy pomiędzy „dobrą” i „złą” dialektyką (na wzór „dobrej” i „złej nieskończoności” u Hegla). Dialektyką dobrą byłby nieustający spekulatywny ruch zapośredniczeń przeciwstawnych momentów i efektu, w postaci nowej całości. Zaś dialektyką złą byłby prosty efekt pojednania „procesu” i „efektu” - czyli substancjalne medium niwelujące wszelkie sprzeczności w niezłożonej („mitologicznej” czy ideologicznej) jedni - absolucie. Można to sprowadzić do napięcia między „zróżnicowanym procesem” i „niewyróżnicowanym efektem”. Różnica ta zostaje odtworzona w przeciwstawieniu Aufhebung (znoszenia-procesu) i Versöhnung (pojednania-stanu) - to znaczy, że utożsamiam „pojednanie” z „byciem zniesionym” (zob. Sosnowski 2013, 111).

2 Historyczna manifestacja tej abstrakcyjnej śmierci pojawia się w Fenomenologii ducha (rozdział Wolność absolutna $i$ terror) jako konflikt między Robespierrem a Dantonem (będący współczesnym wcieleniem tragedii), który w gruncie rzeczy ukazuje krwawe konsekwencje Kantowskiego rygoryzmu moralnego. Czytamy u Hegla: „Owa ogólność, która trzyma się z dala od rzeczywistości ograniczonego rozczłonkowania i której celem jest utrzymanie się w niepodzielnej ciagłości, różnicuje się bowiem zarazem w sobie, ponieważ jest ruchem albo świadomością w ogóle. Mianowicie z powodu własnej abstrakcji dzieli się na tak samo abstrakcyjne terminy skrajne, na prostą, nieugiętą i zimną ogólność [tj. Robespierre - przyp. BW] i na wyizolowaną, absolutną, twardą nieprzystępność i upartą punktowość rzeczywistej samowiedzy [tj. Danton - przyp. BW].[...] - Tak więc z racji tego, że oba te [terminy skrajne] istnieją niepodzielnie w sposób absolutny dla siebie, a zatem nie mogą żadnej swej części przekazać terminowi średniemu, przez który wiązałyby się one [ze soba], ich stosunkiem jest zupełnie niezapośredniczona czyta negacja[...]. Jedynym dziełem i czynem ogólnej wolności jest przeto śmierć, i to pewna taka śmieŕ́, która nie ma żadnego wewnętrznego wymiaru i sensu. Tym bowiem co zostaje zanegowane jest pozbawiony treści punkt absolutnie wolnej jaźni. Totė̇jest to śmieró najz̨imniejsza i najbanalniejsza, śmierí, która nie ma znaczenia wiekeszego nižprzepolowienie główki kapusty çy tyk wody” (Hegel 2002, 380; podkr. BW). 
dla tego, co Nowe. Derrida zaś przeciwnie, uważa, że Heglowskie Aufhebung jest zbyt radykalne, ponieważ nigdy nie uchwytuje resztki, która zawsze opiera się zniesieniuzapośredniczeniu, a co za tym idzie tożsamy ze sobą ruch negatywności-mediacji zostaje nieuchronnie wytrącony przez „dysseminacje”. Według Žižka rozbieżność tych dwóch wykładni może zostać przekroczona w ich „dialektycznej syntezie”, która jednak nie byłaby po prostu jakimś punktem równowagi między nimi, ich uśrednieniem, a raczej czymś odwrotnym:

\begin{abstract}
Można sobie wyobrazić, że odpowiedź Hegla polegałaby raczej na skupieniu się na poziomie, na którym te dwie przeciwstawne krytyki Aufhebung zbiegają się ze soba: ostatecznie Aufhebung sprowadza się do koincydencji dwóch sposobów jego porażki. Na przykład, Heglowski „sąd nieskończony” Die Geist ist ein Knochen [duch jest kością] oznacza koincydencję czystej, absolutnej i niewymuszonej negatywności z bezwładna, nie-dialektyzowalną resztką (Žižek 1996, 179).
\end{abstract}

Innym „ulubionym” Heglowskim przykładem Žižka, który reprodukuję logikę zbiegania się przeciwieństw w sądzie nieskończonym, jest figura Monarchy z Zasad filozofii prawa. Z jednej strony Państwo stanowi racjonalną totalność znosząca przygodność indywidualnych celów, jednak z drugiej strony - tu dokonuje się dialektyczna zmiana perspektywy - okazuje się, że totalność Państwa może się urzeczywistnić tylko dzięki Monarsze jako przygodnej i cielesnej egzystencji (por. Hegel 1969, 277-278). To spekulatywne napięcie, jakie zostaje wygenerowane $\mathrm{w}$ obu przypadkach między tym, co uniwersalne, racjonalne wszechzapośredniczające (ruchome i dynamiczne uogólnienie), a tym, co jednostkowe, resztkowe i opierające się wszelkim formom mediacji (spetryfikowane i statyczne wyszczególnienie) odpowiada na poziomie struktur logicznych relacji między dobrym i złym końcem, między Aufheben a Aufgehobensein, uczasowionym znoszeniem i poza-czasowym pojednaniem itd. Innymi słowy, jak podsumowuje Žižek, „tym, co utrzymuje płynny ruch teleologicznej maszyny jest niesamowity fakt, że ma ona za dużo końców/celów - mówiąc dokładniej, praynajmniej dwa” (Žižek 1996, 113). Pozostaje więc zapytać, jak kończy się religia u Hegla?

W interpretacji Macieja Sosnowskiego ${ }^{3}$ pojednanie religii i filozofii, tj. utożsamienie wyobrażenia i myślenia (bezpośredniości i zapośredniczenia), „musi mieć rzeczywiście źródło

\footnotetext{
3 Odwołuję się tutaj do eseju Sosnowskiego o znaczącym tytule: „...praypadkowość, arbitralność, bezład...”: O pojednaniu religii $i$ filozofii w myśli G. W. F. Hegla. Cytat w owym tytule nawiązuje do dziwacznego związku wyobrażenia i myślenia, które u Hegla nie dotyka tylko formy religijnej, gdyż pojawia się także na gruncie „filozofii przyrody”, a dokładniej w naukowo-filozoficznych próbach ubóstwienia przyrody jako wolności. Filozof przedsięwzięcia te skomentował w następujący sposób: „To, że przypadkowość, arbitralność, bezład uważa się za wolność i rozumność, należy składać na karb zmysłowej formy wyobrażenia. Owa niemoc
} 
bardziej strategiczne niż immanentnie-systemowe" (Sosnowski 2013, 101). W tym sensie dwuznaczności uruchamiane przez wprowadzenie religii do spekulatywnego systemu byłyby nie tyle dialektycznymi dwuznacznościami - będącymi kołem zamachowym całego ruchu tylko niewyraźnymi punktami, mętnymi zagęszczeniami czy arbitralnymi rozstrzygnięciami, dla określenia których Sosnowski ukuł termin techniczny spekulaton. Należy go rozumieć jako wewnętrzną anomalię w ramach samego procesu spekulacji, a-czasowy punkt uczasowionego ruchu dialektycznego: „to duch nierzeczywisty, radykalnie pasywny, duch nie-sprawczy, ale jednak jakoś istniejący w swej »wątłej i efemerycznej egzystencji«” (Sosnowski 2013, 116)4.

Sosnowski dochodzi do zaskakującego rozpoznania w swojej drobiazgowej i wyczerpującej analizie skomplikowanych powinowactw między treścią absolutną, wspólną filozofii i religii, a odrywająca się od niej patologiczna, partykularną i lawirującą na obrzeżach dialektycznego systemu formą religijną (przybierającą postać historyczno-dziejowego chrześcijaństwa). Przyczyną tego nierozumnego i toksycznego dla pojęciowej klarowności czy terminologicznej koherencji związku jest sam Hegel: „ostatecznie protestancki teolog”, czyli „skończony duch subiektywny, uwikłany we własną historię i dziejowe okoliczności”, przywiązany do chrześcijaństwa - „substancjalnej koncepcji prawdy-jako-wieczności w bezgranicznie dynamicznym »systemie« zapośredniczeń” (Sosnowski 2013, 114-115). W tym kontekście warto wspomnieć o konfesyjnej deklaracji Hegla, w której wprost określa siebie jako luteranina, gdy utożsamia poznanie rozumowe z wiara: „Boski duch żyje w swojej gminie, jest w niej obecny. To słyszenie głosu nazwane zostało wiara. Nie jest to wiara o charakterze historycznym. My luteranie - jestem i chce pozostać jednym z nich - mamy tylko owa pierwotna wiare" (Hegel 2013, 113)5.

przyrody zakreśla filozofii granice, toteż czymś najbardziej niestosownym jest wymagać od pojęcia, by miało pojać takie przypadkowości [...]" (Hegel 1990, 266) (zob. Sosnowski 2013, 101).

${ }^{4}$ Jak dodaje autor w swojej metaforycznie próbie definicji spekulatonu, który pojawia się w systemie Hegla wraz z chrześcijaństwem: ,Jednocześnie czystość owego spekulatonu - o ile przeciska się przez wąską bramę artykulacji - właśnie we wspomnianej efemeryczności - jest niemożliwa, zawsze musi się jakoś uformować, przejawić, więc dlaczegóż by nie jako prawda chrześcijaństwa (spoza czasu, tzn. spoza dziejów, na zasadzie decyzji autora)? Spekulaton jest więc pewnym zawieszeniem dialektyki, statyczną hipostazą jej ruchliwości, natomiast heglowskie określenie religii chrześcijańskiej jest możliwe tylko dlatego, że czerpie użytek ze spekulatonu i go ukonkretnia, co więcej, w swej partykularnej formie/treści (chrześcijańskiej) uwiecznia i prezentuje chrześcijaństwo jako jedyna postać owego abstrakcyjnego (związanego ze zła nieskończonościa) tworu, tworu przecież bezforemnego (beztreściowego). Oczywiście w ten sposób drążąc tę niejasność, cofamy Hegla na pozycje około-schellingiańskie, [...]"(fragment ten pojawia się w nieopublikowanej wersji tekstu).

${ }^{5}$ Kwestia religijności Hegla jako osoby jest co najmniej dwuznaczna. Z jednej strony nigdy nie odcinał się on od swoich luterańskich korzeni (ukończył przecież seminarium duchowne w Tybindze), przyjaźnił się z teologami spekulatywnymi (Karlem Daubem i Konradem Marheinekem), a pod koniec życia wygłaszał nawet mowy celebrujące trzystulecie konfesji augsburskiej (zob. Pinkard 2000, 627-631). Z drugiej strony jego wykłady z filozofii religii spotkały się z surową krytyką ze strony ortodoksji protestanckiej - między innymi z ich powodu wybuchł konflikt Hegla z Friedrichem Schleiermacherem (ten drugi zablokował akces Hegla do Berlińskiej Akademii Nauk) - i spekulatywnego teizmu (Christiana H. Weissego i Immanuela H. Fichtego), a także „zainspirowały” do odrzucenia teologii protestanckiej i chrześcijaństwa w ogóle najbardziej radykalnych przedstawicieli pierwszego pokolenia „lewicy heglowskiej” - Arnolda Rugego i Bruno Bauera. Chociaż 
Problem religii konfrontuje nas wobec tego ze wspomnianym już i centralnym dla dialektyki pęknięciem pomiędzy punktową, historycznie określoną jednostkowością samowiedzy a ogólnym wszystko zapośredniczającym systemem myślenia jako myślenia. Słowem, z luką między subiektywną dziejowością ewokującą zły „koniec końców” (zatrzymanie procesu reprezentowane przez Versöhnung) a obiektywną strukturą logiki, w której ruch pojęciowy jest dobrym „końcem bez końca” (nieustający ruch Aufhebung). Stajemy tutaj przed problemem meta-dialektyki, znoszenia samego znoszenia, nieskończonej pracy spekulacji i jej nie-spekulatywnego finału, systemu i jego anty-systemowej resztki (oraz ich wzajemnego zapośredniczenia).

$\mathrm{Na}$ tym tle religia dzieli zatem los innych spekulatonowych, nie-dialektyzowalnych, sfetyszyzowanych resztek, tych unieruchomionych, zatrzymanych momentów, które nieustannie wydala $z$ siebie ruch spekulacji. Wydalanie, odpadanie i uwalnianie od systemu tego, co go od wewnątrz zatyka i tamuje, jest kluczowe dla jego odpowiedniego funkcjonowania. Metafory trawienne są w tym kontekście jak najbardziej uzasadnione o istotowej relacji dialektyki Hegla z metaforyką trawienno-wydalniczą pisał już w Glas Jacques Derrida, a także silnie nim inspirowany Werner Hamacher w Pleromie (uczta eucharystyczna podczas Ostatniej Wieczerzy stanowi dla nich wzorcowy posiłek Ducha) ${ }^{6}$. Również Žižek zabiera głos w tej sprawie. Dla filozofa kluczowe jest odrzucenie krytyki Heglowskiego systemu jako exemplum „rozbuchanej ekonomii oralnej” - idei absolutnej jako absolutnego pochłaniacza zasysającego w sobie cała przedmiotową rzeczywistość:

w standardowym krytycznym odczytaniu Heglowski absolutny podmiot-substancja jest przedstawiony w całkowitym zatwardženiu - zatrzymuje w sobie pochłoniętą treść. Albo, jak to ujął Adorno, w jednym ze swoich komentarzy [...], Heglowski system jest „żołądkiem obróconym w rozum”, udającym, że połyka całą niestrawną Inność. Ale co $\mathrm{w}$ takim razie $\mathrm{z}$ ruchem przeciwnym, z Heglowskim wydalaniem, defekacją? (Žižek 2012, 399)7.

wspomniane kontrowersje dotyczyły raczej filozofii Hegla niż jego samego jako filozofa, który - jak zgodnie podkreślaja wszyscy jego biografowie, od Rozenkranza po Pinkarda - był jednak nieortodoksyjnym protestantem.

${ }^{6}$ Analizę dekonstrukcyjnych lektur Hegla autorstwa Derridy i Hamachera w kontekście procesu trawienia przeprowadza Sosnowski w tekście o dość wymownym tytule: „Niestrawności: O dialektyce i wymiotowaniu” (Sosnowski 2017).

${ }^{7}$ Dla Słoweńca to właśnie „wydalenie” jest wewnętrznym warunkiem koniecznym całego ruchu znoszeniaprzyswajania. Zresztą Heglowska logika puszczania wolno czy uwalniania resztki, materialnego residuum-natury (w słynnym finale Logiki), bezpośrednio przywołuje na myśli proces defekacji. Samo pojęcie resztki czy reszty odpadającej od dialektycznego przebiegu (którą tak fetyszyzuje cała myśl dekonstrukcyjna) jest odpowiednikiem „pra-fetysza wszystkich fetyszów”, pierwotnego ekskrementu, czyli po prostu gówna. Dlatego jeśli mowa jest o nie-dialektyzowalnej resztce będącej nawozem dla samej dialektyki Aufheben, należy pamiętać, że nawóz 
Proces permanentnego znoszenia - przyswajania i spożywania - przez żarłoczną dialektykę każdej napotkanej, choćby najbardziej wsobnej i opornej treści ma swój przeciwstawny ruch w postaci „puszczania wolno” (Freilassen), pozostawiania resztek i ekskrementów. Duch dokonując samooczyszczania na drodze do wiedzy absolutnej, zapośrednicza się ze wszystkimi przeszkodami i zanieczyszczeniami (patologiami partykularnej bezpośredniości takimi jak np. luteranizm Hegla jako historyczne subiectum) poprzez ich odrzucenie, one jednak jako uwolnione, autonomiczne byty-w-sobie „wzajemnie oddziaływają” z równie samoistnym, czystym duchem.

Wszystko pochłaniający duch (absolutny podmiot-substancja) zbiega się z nieprzenikniona, wyrzucona poza jego obręb ekskrementalną, niestrawioną resztką - oba momenty wzajemnie napędzają się i jednocześnie powstrzymuja (swoje separatystyczne tendencje) w kruchym medium pośredniości, które wytwarzają. W systemie Heglowskim matryca dla tego ruchu uwalniania jest zwieńczenie Logiki, w którym idea puszcza z siebie wolno przyrodę (świat zewnętrzny) w jej własnej postaci, ustanawiając tym samym właściwego ducha jako rozwijającego się poza przyrodą ${ }^{8}$ Uwalnianie przyrody, zewnętrza jest w tym sensie wewnętrznym samo-zniesieniem ducha, koniecznym i integralnym momentem jego własnej konstytucji.

Dlaczego przypominam o tym w kontekście końca religii? W jaki sposób problem „spekulatywnego wydalania” odnosi się do wyróżnienia chrześcijaństwa jako spekulatonu Heglowskiego systemu? Otóż ten spekulaton jako „koniec końców” wkradający się do spekulatywnej machiny zapośredniczającej formy przedmiotowe „bez końca” stanowi z ową dialektyka paradoksalną i nierozłączna jedność, choć ciągle różnicującą się od wewnątrz. Oba końce dobry, pracujący (filozofia) i zły, nie-pracujący (religia) nie prowadzą do żadnego ostatecznego scalenia, ani równie finalnego rozdzielenia i wzajemnego unicestwienia, ani tym bardziej nie tworzą harmonijnej formy intersubiektywności. Są raczej zawsze-już nieudaną komunikacją pośrednią, czyli nieredukowalnym konfliktem jako jednym możliwym polem wzajemnego porozumienia-odniesienia: niekończącym się końcem końców. Innymi słowy,

to określenie na gnój. Nie sposób zatem ominąć - w kontekście spekulacji - tych wszystkich eksrementalnych (w najbardziej fizjologicznym sensie) konotacji. Na kontaminacji tego, co najbardziej wzniosłe i spekulatywne, z tą obsceniczną ciemną materialnością polega w ostateczności - tak fascynująca Žižka - paradoksalna i antynomiczna istota Heglowskiej logiki. Skądinąd, w błyskotliwej historii gówna autorstwa Floriana Wernera pojawia się ciekawa wzmianka o Heglu: „Przez ten czas [trawienia - przyp. BW] jedzenie wchodzi w kontakt z najbardziej intymnymi częściami naszego ciała: wargami, językiem, podniebieniem, żołądkiem i wreszcie odbytem. Z tego powodu Georg Wilhelm Friedrich Hegel określił proces defekacji mianem »odpychania siebie od siebie«" (Werner 2014, 34). Defekacja jako „odpychanie siebie od siebie”, to najlepsza definicja tego uzupełniającego i odwracającego Aufhebung ruchu spekulatywnego uwalniania (befreien, ablegen) i wyzbywania się.

8 ,To najbliższe otwarcie (Entschluß) czystej idei ku określeniu siebie jako idei zewnętrznej [tj. uwolnienie z siebie realnego, bezpośredniego bytu, przyrody - przyp. BW] ustanawia dla niej tylko zapośredniczenie, z którego pojęcie wznosi się jako wolna egzystencja, która z zewnętrzności wróciła do siebie samej, doprowadzając swoje wyzwolenie do końca w nauce o duchu [...]” (Hegel 2011b, 705-706). 
warunkiem czystego myślenia pojęciowego (Gedacht) jest nie-pomyślane wyobrażenie (Andacht $\left.t^{9}\right)$, residuum religijnej bezpośredniości, w którym to pierwsze musi się refleksyjnie odbić (w tym sensie religia to także kryptonim ideologicznej plamki niewymazywalnej $z$ antyideologicznej dialektyki).

\section{2.}

Skoro chrześcijaństwo w swojej partykularnej formie/treści ukonkretnia spekulaton, pora sięgnąć do istoty tego chrześcijaństwa, odsłonić jego określenia, które zyskuje w spekulatywnej wykładni Hegla. Pozwoli to na przejście od analizy kategorialnej - omawiana strukturalna relacja filozofii i religii - do konkretno-dziejowego badania fenomenu chrześcijaństwa (zwrot ten jest odwrotny względem samej Heglowskiej logiki, która jest ruchem regresywnym - od tego, co wtórne, do tego co pierwotne). Skoro do tej pory dwuznaczna i wpisana w dialektykę samego Aufhebung była systemowa funkcja formy religijnej, to czy jej treść - chrześcijaństwo - odzwierciedla na innym poziomie tę samą logikę? Czy historyczny los chrześcijaństwa interpretowanego przez Hegla także uwikłany jest w podwójność końców? Jak w ogóle powiązać „religię jawna”10 z czasowościa, czy ona w ogóle może mieć swój koniec? Mówiąc krótko, jak pomyśleć wzajemne nałożenie się na siebie wiecznego i czasowego (historycznego) charakteru chrześcijaństwa? Gdzie wieczna prawda „religii jawnej” przecina się z jej historyczną i ziemską postacią?

Przed pułapką „złej nieskończoności” pytań bez końca może ocalić jedynie sięgnięcie do samego rdzenia problemu. Już Karl Löwith w swoim kanonicznym i konserwatywnym - odczytaniu filozofii autora Fenomenologii rozpoznał wagę i znaczenie interesujących nas niespójności i dwuznaczności Heglowskiego pomysłu na religię:

Za sprawą tego rozróżnienia, wyniesienia religii poza formę uczucia i przedstawienia $\mathrm{w}$ postaci pojęcia dokonuje się u Hegla pozytywne usprawiedliwienie religii

\footnotetext{
9 Andacht jest dla Hegla właściwą religii formą świadomości, czymś co określa jako „rejon duchowego pokrzepienia i skupienia" (der Andacht und des Genusses) (Hegel 2006a, 20), w którym nie zostaje jeszcze osiagnięty ostateczny cel - wiedza absolutna. Andacht jest jakby przed-myślowa geneza samego myślenia, ruchem ku myśleniu, religijnym skupieniem ostatecznie „niedochodzącym do pojęcia”. Dlatego Światosław Florian Nowicki interpretujacc ten termin - który odgrywa dla niego rolę praformy absolutu - rozważa jego przekład przy użyciu terminu „niedomyśl” (zob. Hegel 2006a, XXIII-XXVI).

10 „Religia jawną” jest dla Hegla oczywiście religia chrześcijańska, czyli religia, w której objawił się Bóg jako całkiem jawny, niemający w sobie żadnej tajemnicy. Dlatego „religia jawna” (die offenbare Religion) jest de facto „religia objawioną” (die geoffenbarte Religion) (o różnicy między oboma terminami będzie jeszcze w tekście mowa). „Ta wiedza ducha dla siebie - pisze Hegel - jakim jest on sam w sobie, jest bytem samym w sobie i dla siebie wiedzącego ducha, doprowadzoną do końca, absolutna religią, w której jest czymś jawnym [offenbar] to, czym jest duch, Bóg; jest to religia chržeścijańska”" (Hegel 2006a, 83).
} 
chrześcijańskiej, dokonuje się zaražem również jej krytyka. Z dwuznacznością tego rozróżnienia wiąże się wszelka poheglowska krytyka religii, ale stąd też wywodzi się rozłam w szkole Heglowskiej na lewicę i prawicę (Löwith 2001, 401).

Jak podsumowuje dalej autor, „tym bowiem, co historycznie wyłoniło się z Hegla dwuznacznego »zniesienia«, była zdecydowana destrukcja filozofii i religii cbrześcijańskiej” (Löwith 2001, 401). Mimo że Hegel jako duch subiektywny, szczególnie u schyłku swojego życia, domagał się uznania chrześcijańskiego charakteru swej filozofii, to jako duch obiektywny, obnażając dwuznaczność „zniesienia” religii w filozofii (ostateczne unicestwienie versus radykalna afirmacja), zdemaskował pęknięcie wewnątrz samego chrześcijaństwa, jego strukturalny kryzys. Działo się tak bowiem:

przecinieństwo uczucia, bezpośredniego oglądu i refleksji oraz wiedzy dotyczy samej religii chrześcijańskiej. Zawiera ona $\mathrm{w}$ sobie samej $\mathrm{w}$ istotny sposób poznanie, co spowodowało, że rozwinęło się ono w całej swojej konsekwencji jako forma i jako swiat formy, a tym samym zarazem przeciwstawiło się formie, w której owa treść występuje jako dana prawda. Na tym polega konflikt naszej epoki (Hegel 2006a, 20).

Forma poznania (filozofia) wyodrębniła się od formy religijnej, w której miała swoją genezę i przeciwstawiła się jej - mimo że treść obu tych form, czyli ich przedmiot, jest ten sam wieczna prawda w swojej obiektywności, tzn. Bóg ${ }^{11}$.

Dlatego w filozofii poheglowskiej religia chrześcijańska będzie występowała w stanie permanentnego kryzysu, który w zależności od zajmowanego stanowiska będzie się albo pogłębiało (młodoheglowska krytyka religii - od Davida Straußa przez Feuerbacha do Marksa), albo powstrzymywało (staroheglowski reakcjonizm Karla Friedricha Göschela, Johanna Philippa Gablera czy Heinricha Gustava Hotho) (zob. Löwith 2001, 42). Dla prawicy filozoficzna prawdą chrześcijaństwa u Hegla będzie pojednanie tego, co ludzkie z tym, co boskie, poświadczone we wcieleniu się Boga w człowieka w ramach ziemskiego „Królestwa Bożego”; dla lewicy zaś jedność człowieka i Boga ulegnie absolutnemu rozdarciu - w humanistycznym ateizmie Feuerbacha i młodego Marksa. Niemniej jednak koniec religii

${ }^{11}$ Jak doprecyzowuje Hegel, ,ich [filozofii i religii - przyp. BW] wspólną cechą jest to, że są religia; to, co je odróżnia wiąże się wyłącznie z formą religii. Różnią się one specyfiką swego zajmowania się Bogiem” (Hegel 2006a, 21). Sytuacja się jeszcze bardziej komplikuje, gdyż mamy religię $\mathbf{w}$ formie religijnej i religię $\mathbf{w}$ formie filozoficznej, które jednoczy to, iż sa wspólnie odniesione do absolutnej treści. O zawiłych i zaskakujących konstelacjach, które tworzą forma i treść, wyobrażenie religijne i myślenie pojęciowe w Heglowskiej filozofii religii, zob. Sosnowski 2013, 98-106. 
chrześcijańskiej jako spoiwa pola społecznego był faktem niekwestionowalnym ${ }^{12}$ : legł w gruzach fundament przednowoczesnego świata zachodniego, a filozofia Hegla miała wyjaśnić zaistniały kryzys, który - jak zobaczymy - wcale nie był historyczną przygodnościa, lecz konieczną konsekwencją samego pojęcia religii jawnej. Być może kwestia sporna między lewica a prawicą heglowską - pojednanie czy rozdacie - jest źle postawiona i właśnie w absolutnej tożsamości tego, co ziemskie z tym, co transcendentne, we wcieleniu jako modi pojednania, należałoby szukać śmierci Boga jako takiego, jego wewnętrznego rozdarcia? Dialektyka sugeruje, że pojednanie jest rozdarciem, a rozdarcie jest pojednaniem: jak zatem ta spekulatywna tożsamościowa-różnica odnosi się do paradoksalnej prawdy chrześcijaństwa, którą odsłonił Hegel?

\section{3.}

Interesująca nas figura końca religii chrześcijańskiej, jak już zauważyliśmy, nieuchronnie ewokuje problem czasowości, ponieważ sam koniec (czy końce) jest istotowym określeniem samego czasu - ostatecznie pojęcia czasu, na najbardziej abstrakcyjnym poziomie, nie sposób pomyśleć poza horyzontem początku i kresu. Sama zaś religia nawet w potocznym znaczeniu dotyczy przecież spraw ostatecznych, czyli tego, co na końcu albo raczej po końcu nowego początku. Trudno zatem znaleźć bardziej uprzywilejowane pole dla refleksji o końcu niż religia, z kolei owa refleksja, jeśli ma mieć miano filozoficznej, powinna powiązać pytanie o kres z pytaniem o czas. Chodzi tutaj bowiem o kres czasu. W omawianym kontekście staje się to tym bardziej uzasadnione, że Hegel w Encyklopedii nauk filozoficznych (będącej pełną i skondensowaną manifestacja jego systemu) dokonuje ekspozycji czasowości właśnie w rozdziale poświęconym „religii objawionej” (Hegel 1990, 564-570/§564-571). W błyskotliwej interpretacji Catherine Malabou - zaprezentowanej w L'Avenir de Hegel ten niewielki fragment dotyczący Boga staje się jednym z trzech filarów - obok Człowieka i Filozofa - wypracowywanego przez autorkę pojęcia plastyczności ${ }^{13}$. Filary te są trzema

12 Co ogłosił już Marks otwierają swój „Wstęp” do Prayyczynku do krytyki heglowskiej filozofii prawa: „W Niemczech krytyka religii jest już w zasadniczych zarysach ukończona” (Marks 1960).

13 Malabou, obok trzech figur plastyczności (Człowieka, Boga i Filozofa), lokalizuje także w myśli Hegla trzy znaczenia samego pojęcia plastyczności: 1) w Estetyce - rzeźba jest sztuką plastyczna par excellence; 2) koncepcja „plastycznego indywiduum” z Wykładów z historii filozofii, czyli historycznej indywidualności egzemplarycznej i substancjalnej - takiej jak Perykles, Sokrates czy Platon (rozumianych jako formy ducha w szczegółowym ucieleśnieniu); 3) pojęcie „plastyczności filozoficznej” z „Przedmowy do drugiego wydania” Nauki logiki, które oznacza zarówno samą istotę filozofii w swojej spekulatywnej treści, jak i postawę czy dyspozycję podmiotu filozofującego. Jak czytamy u Hegla: „Nie ma takiego przedmiotu, którego przedstawienie mogłoby samo w sobie i dla siebie być w zupełności tak ściśle i immanentnie plastyczne, jak przedstawienie rozwoju myślenia w jego konieczności. Żaden inny przedmiot nie mógłby tak ściśle wiązać się z postulatem takiej plastyczności [...]. Plastyczny wykład wymaga plastycznego zmysłu ujmowania i rozumienia. Ale takich plastycznie podatnych młodzieńców i mężów, którzy spokojnie, rezygnując z własnych refleksji i własnej ingerencji, czyli tego, czym ich własna myśl z taką niecierpliwością chce się wykazać, takich słuchaczy podążających tylko 
etapami filozofii ducha (wszystkie te figury pochodzą z drobiazgowego odczytania odpowiednich fragmentów Heglowskiej Encyklopedii ${ }^{14}$ ), będącymi dla Malabou plastycznymi instancjami, tj. miejscami ustanawiania się podmiotowości. Innymi słowy, są one momentami samookreślania się ducha ${ }^{15}$ - Greckim (Człowiek), nowoczesnym (Bóg) i absolutnym (Filozof) - które wytwarzają własną formę czasowości albo są raczej trzema interwałami, pęknięciami w procesie wewnętrznego formowania się czasu.

W tym sensie ujmowany w perspektywie czasowości Bóg jest nieustannym procesem samookreślania się - od wcielenia do śmierci. Wkraczając w porządek czasu (inkarnacja w człowieka), czas stwarza, a umierając na krzyżu, przeżywa własną śmierć zmartwychwstaje i tym samym unicestwia koniec definitywny (śmierć). Można postawić hipotezę, że boskie kończenie to wzorcowe kończenie bez końca, to dobry, dialektyczny koniec już zapośredniczony z kończącym końcem, to sama nie-ostateczność refleksyjnie skierowana do ostateczności jako swojego momentu itd. Jednak z drugiej strony, z perspektywy myślenia religijnego, Bóg ujmowany w kategoriach mesjańskich jest tym, który nadejdzie i ostatecznie zbawi świat, odkupi ludzkość, doprowadzając do wypełnienia się czasu - za jego sprawą koniec wreszcie się ziści, czyli dokończy. Bóg jako interwał w czasie dokonuje radykalnego podwojenia samego czasu, linearna temporalność bez końca nakłada się na teleologiczną obietnicę końca, chronologia zderza się z wiecznością, czyli Bóg jest by przywołać podstawową formułę spekulacji - czasowością czasowości i a-czasowości ${ }^{16}$. Jakie konsekwencje płyną z tego dla Heglowskiej filozofii religii? Jak ów „dialektyczny” Bóg ma się do chrześcijańskiej doktryny?

Malabou konfrontuje się z tą dwuznacznością czy plastycznością Boga u Hegla w swoim odczytaniu gęstego i bardzo abstrakcyjnego rozdziału o „Religii objawionej”

za istotą rzeczy, jak ich przedstawia Platon, nie można by wprowadzić do nowoczesnego dialogu” (Hegel 2011a, 24-25). To trzecie miejsce plastyczności, ze względu na swój najbardziej ogólno-filozoficzny charakter ma centralne znaczenie dla interpretacji Malabou (zob. Malabou 2006, 9-10).

14 Filozofka przyszłości Hegla (brak przyimka otwiera całe spektrum możliwości, które dobrze oddają wieloznaczne intuicje autorki: chodzi jej bowiem o przyszłość w Heglu, dla Hegla i po Heglu) poszukuje w Encyklopedii (często marginalizowanej we współczesnych lekturach filozofa), która stanowiła przez lata podstawę dla najbardziej szkolarskich i ortodoksyjnych wykładni. Jednak zdaniem Malabou odczytywany z perspektywy figury plastyczności ,tekst ten [stanowiąc - przyp. BW] [...] ostateczny wyraz Heglowskiej myśli, ujawnia się w swojej łagodnej dojrzałości” (Malabou 2006, 20).

15 Dla Malabou dialektyczny proces jest ruchem samookreślania się podmiotu-substancji, który napędza sprzeczność wytwarzająca się pomiędzy zachowywaniem jednostkowego określenia i rozpływaniem się wszelkich określeń w ogólności - autorka nawiązuje tu do „Przedmowy” do Fenomenologii, gdzie czytamy: „Z racji swej prostoty, czyli swego równania się sobie, substancja jawi się jako coś stałego i trwałego. Ale to [jej] równanie się sobie jest również negatywnościa; w wyniku tego, owo stałe istnienie przechodzi w swoje rozpłynięcie się [Auflösung]” (Hegel 2002, 46-47).

${ }^{16}$ Nawiązuję tutaj do struktury spekulatywnej definicji absolutu: „tożsamość tożsamości i nietożsamości. Pojęcie to można by uważać za pierwsza, najczystszą albo najbardziej abstrakcyjną definicję absolutu i rzeczywiście by nią było, gdyby w ogóle szło tu o taką formę jak definicje i taką nazwę jak absolut” (Hegel 2011, 75-76; podkr. $\mathrm{BW})$. 
z Encyklopedii. Już na początku zwraca ona uwage na znaczenie samego przymiotnika „objawiona” (geoffenbarte), wyrażającego specyfikę chrześcijańskiego momentu religijnego. Należy pamiętać, że chrześcijaństwo w Fenomenologii występuje jako „religia jawna” (offenbare Religion), natomiast w Wykładach z filozofii religii mowa jest o chrześcijaństwie jako „Religii absolutnej” (jawnej i objawionej). Różnica pomiędzy pojęciami „jawna” i „objawiona” odnosi się do dwóch poziomów, z którego zjawisko religii jest rozpatrywane: „religia jawna” przedstawia punkt widzenia podmiotowej świadomości, „religia objawiona” zaś jest obiektywna, czyli dana podmiotowi z zewnątrz ${ }^{17}$. W encyklopedycznej wykładni obie perspektywy (subiektywna i obiektywna) zbiegają się ze sobą i wzajemnie sprzęgaja, odsłaniając tym samym absolutność objawionej religii, a dokładniej: „boskie objawienie præzez Boga siebie samego, absolutne samo-objawienie" (Malabou 2006, 81). Ten samo-objawiający się Bóg staje się według Malabou genezą nowoczesnej koncepcji podmiotowości, która „nie tylko wydobywa z niego [Boga - przyp. BW] swoje istotne cechy, ale, co ważniejsze, ukazuje, jak cechy te sa już obecne w Bogu" (Malabou 2006, 81).

Dla Hegla Bóg w swojej strukturze jest podmiotem, a co za tym idzie, boska figura zarówno antycypuje nowoczesne subiectum, jak i podlega tym samym ograniczeniom, co skończona podmiotowość. Boski proces samo-objawienia jest „stawaniem się podmiotem" przez substancję: od Boga Ojca jako potencjalnej substancji przez podmiotowe samookreślenie w Synu do pojednania podmiotu i substancji w Duchu Świętym. Teza o homologii Boga i nowoczesnego podmiotu stanowi clou interpretacji Malabou, która nawiązuje do Heglowskiego komentarza do \564 Encyklopedii otwierającego rozdział „Religia objawiona":

\begin{abstract}
Do tego, aby w sposób właściwy i określony ująć myślą to, czym jest Bóg jako duch, niezbędna jest gruntowna spekulacja. Przede wszystkim w grę wchodzą tu następujące twierdzenia: Bóg jest tylko o tyle Bogiem, o ile zna samego siebie; z kolei to, że zna on siebie jest pewną samowiedzą w człowieku i wiedzą człowieka o Bogu, która staje się następnie tym, że człowiek zna siebie w Bogu”' (Hegel 1990, 565; podkr. BW).
\end{abstract}

Zatem według Hegla warunkiem boskiej samowiedzy - jego refleksyjnego bytu-dla-siebie jest wiedza człowieka o Bogu, tzn. w samowiedzy człowieka konstytuuje się samowiedza Boga! Jak wobec tego nieskończony Bóg może być jednocześnie skończony? Jak absolutna

\footnotetext{
${ }^{17}$ Jak pisze Hegel o tej relacji: „religia, która sama dla siebie jest jawna, jest nie tylko jawna, lecz również jest religia, która jest objawiona, a rozumie się przez to, że z jednej strony została objawiona przez Boga, że Bóg sam dał ludziom siebie poznać, a z drugiej strony ze względu na to, że jest objawiona, jest ona religia pozytymna, w tym sensie, że przyszła do człowieka z zewnątrz, że została mu dana” (Hegel 2006b, 203).
} 
substancja - a-czasowa i wszechmocna - staje się uczasowioną, historycznie określoną jaźnią? Słowem, jakie są ostateczne implikacje wcielenia?

Odpowiedź znajduje się w dialektycznej koncepcji wcielenia jako kenosis, czyli kenozy, boskiego samowyobcowania - a więc w idei Boga wybrakowanego i niespójnego. Pojęcie „kenozy” pochodzi od greckiego słowa kénōsis, które oznaczało „wypróżnienie”, „ogołocenie” czy „porzucenie”. W tradycji teologii protestanckiej „kenoza” odnosiła się do samouniżenia się Boga przybierającego ludzką postać i ponoszącego śmierć na krzyżu18; termin ten (w innej formie gramatycznej) pojawia się we fragmencie Listu do Filipian Pawła: „On istniejąc w postaci Bożej, nie skorzystał ze sposobności, aby na równi być z Bogiem, lecz ogołocił samego siebie [heauton ekenōen], przyjąwszy postać sługi, stawszy się podobnym do ludzi” (Flp 2, 6-7). Bóg wypróżnia się ze swojej boskości i już ogołocony wciela się w człowieka, ustanawia różnicę w sobie i rozdwaja się, odróżniając od siebie Syna określonego jako inny poza nim. W Synu, czyli określeniu różnicy, świat odpada (Abfall), oddziela się od jedności z Ojcem. By przywołać omawiany już schemat, Bóg puszcza z siebie wolno człowieka w osobie Chrystusa - ten wcielony Bóg-jako-podmiot jest efektem spekulatywnego wydalania Boga-jako-substancji. Absolutna wolność idei (Boga) polega na tym, że „w swym określaniu, pra-podziale [Urteil] puszcza ona to, co inne, jako coś wolnego, samoistnego. Tym Innym, puszczonym wolno jako coś samoistnego, jest świat w ogóle" (Hegel 2006b, 257). Heglowską nazwą dla owego boskiego wydalania czy uwalniania jest Entäußerung ${ }^{19}$ (oddzielenie od jaźni poprzez jej eksterioryzację), czyli Lutrowy przekład greckiego kenosis:

18 Interesujące w tym kontekście wykorzystanie pojęcia kenosis proponuje Gianni Vattimo, który „,śmierć Boga" poprzez samouniżenie wiąże z procesem sekularyzacji. Wcielenie jest tu rozumiane jako oddanie przez Boga domeny boskości człowiekowi, czyli na poziomie społecznym jako proces prywatyzacji religii, który urzeczywistnia w pełni jej istotę. „Skoro jest to sposób - pisze Vattimo - w jaki słabnięcie Bytu dokonuje się jako boża kenosis, która stanowi jądro historii zbawienia, sekularyzacji nie podobna dłużej postrzegać jako porzucenia religii, należy ją raczej widzieć jako paradoksalne spełnienie religijnego powołania Bytu" (za: Zabala 2010, 25).

$19 \mathrm{~W}$ polskich tłumaczeniach Hegla termin Entäußerung jest przekładany, w zależności od kontekstu, jako „wyeksterioryzowanie” (propozycja stosowana szczególnie przez Adama Ladmanna) bądź „wyzewnętrznianie” (tłumaczenie to zaproponował Światosław Florian Nowicki w swoim przekładzie Fenomenologii). Natomiast Malabou przekłada Entäußerung jako „wyobcowanie” (alienację), chociaż w ten sposób jest na język polski tłumaczone Heglowskie (a potem utrwalone w całej tradycji marksistowskiej) pojęcie Entfremdung. Filozofka, posiłkując się interpretacją Bernarda Bourgeoisa, rozróżnia oba terminy w sposób następujący: „Entfremdung oznacza ruch wywłaszczenia, który zmienia zarówno formę, jak i treść, natomiast Entäußerung zmienia tylko formę [...] w kontekście religijnym jest wyobrażeniowym wyrazem boskiego wywłaszczenia, jego przedstawieniem w formie wyobrażenia” (Malabou 2006, 91; przyp. 2). Ostatecznie decyduje się ona przekładać Entfremdung za pomocą francuskiego terminu extranéisation, któremu brakuje ścisłego odpowiednika w polszczyźnie, a znaczenie ma przybliżone „wywłaszczeniu”. Żeby nie komplikować nadmiernie i tak zawiłej terminologii stosowanej przez Hegla i jego komentatorkę, będę posługiwał się już przyswojonymi na gruncie języka polskiego przekładami: Entäußerung jako „wyeksterioryzowania” (ew. wyzewnętrzniania czy wyzbycia się) a Entfremdung jako „wyobcowania” (ew. alienacji). Chociaż, należy to podkreślić, bardziej ścisłym tłumaczeniem Entäußerung jest „eskterioryzacja”, co oddaje techniczny charakter tego pojęcia, a nie „wyzbycie się”, które w niemieckim ma swój odpowiednik w Veräußerung, które pojawia się na przykład w pismach Marksa. 


\begin{abstract}
Wraz z tym Entäußerung czy „wyobcowaniem” [alienation] - zauważa Malabou - Hegel wykuwa ruch logiczny, który staje się konstytutywny dla rozwoju boskiej istoty. Bóg z konieczności odrywa się od siebie samego w swoim samo-określeniu [...]. Sprzeciw teologów, wobec tego podejścia, koncentrują się na jednej kwestii: Bóg Hegla jest bez. prayszzłości (Malabou 2006, 82-83).
\end{abstract}

Bóg bez przyszłości jest faktycznie „śmiercią Boga”, jest końcem Boga jako transcendentnej istoty, ogołoceniem jego wszechmocy: nic już nie obiecuje i nie jest przez nikogo oczekiwany. Słowem, Bóg staje się ruchem nieustającego kończenia się samej boskości poprzez jej urzeczywistnianie w negatywnym ruchu samo-określenia. Boskość istnieje w swoim wybrakowaniu, w miejscu pęknięcia swojej istoty. Negatywność zaś, będąc znakiem braku przyszłości, ewokuje koniec Boga.

Cały rozdział o „Religii objawionej” organizuje się wokół pojęcia eksterioryzacji (Entäußerung) oznaczającego „kenozę”, Boską ofiarę w swoim synu Chrystusie, który umiera na krzyżu: wcielenie jest wyobcowaniem się Boga od samego siebie, a śmierć jest wkroczeniem innobytu do Boga. „Taka dialektyczna interpretacja Entäußerung wprowadza lukę w Bogu i rujnuje nadobfitość [superabundance] Ojca” (Malabou 2006, 91), co, jak dodaje Malabou, oddziałuje także na wspólnotę wiernych. Autorka w omawianym rozdziale podejmuje szczegółową i wyczerpująca analizę wszystkich ruchów myślowych, ich momentów i kroków logicznych w Heglowskiej „Religii objawionej” (tj. trzech momentów pojęcia „prawdziwej religii” i trzech „sylogizmów objawienia”) obrazujących przejście od religijnej wiary do filozoficznego myślenia (por. Malabou 2006, 85-90). Jednak dla naszych dalszych rozważań istotna jest konkluzja wyprowadzona przez autorkę:

Wyobrażeniowa forma zostaje dialektycznie zniesiona w zbiorowym kulcie i w prostocie myślenia, czyli: w powrocie do jaźni i w duchowym przyswojeniu śmierci Chrystusa przez konkretne jednostkowe podmioty. Samo-objawienie, z jednej strony ma wyobrażeniową formę kolejnych i obiektywnych wydarzeń, a z drugiej strony ma formę podmiotowego wchłonięcia we wspólnotę wiernych (Malabou 2006, 90). 
Chrześcijańska triada Doktryny, Wiary i Rytuału jest skonstruowana według Heglowskiego podziału wnioskowania na trzy sylogizmy ${ }^{20}$ : istnienia (J-S-O), refleksji (O-J-S), konieczności (S-O-J). W pierwszym z sylogizmów (Chrystologicznym) terminem średnim jest szczegółowość zmysłowego istnienia - Chrystusa; w drugim (sylogizmie negatywnej identyfikacji wierzącego z Chrystusem) terminem średnim jest jednostkowość konkretnych podmiotów - wiernych; natomiast w trzecim (sylogizm wspólnoty wierzących) terminem średnim jest to, co ogólne, czyli substancjalne połączenie wspólnoty jako totalności swoich uszczegółowień - gmina (zob. Malabou 2006, 88-89). Wyznawca zgormadzony w gminie religijnej, podobnie jak jego Bóg, jest ruchem ,polegającym na wyzbywaniu się [sich zu entäusseren] swojej bezpośredniej naturalnej określoności i swojej własnej woli oraz na sylogistycznym łączeniu się w bólu negatywności z owym wzorcem [Chrystusem - przyp. BW]" (Hegel 1990, 568).

Bóg wyzbywa się swojej transcendencji i istnieje we wspólnocie Ducha Świętego ${ }^{21}$, która pozbawiona jest przyszłości, czyli oczekiwania na przyjście zbawiciela: prawda terminem średnim - jest „ból negatywności”22, tzn. cierpienie Syna (czyli jednocześnie cierpienie Boga, który kona na krzyżu i cierpienie wiernych, którzy nie znają zaświatowego Pana). Właśnie negatywność jest owym źródłowym brakiem w Bogu, który uniemożliwia mu spełnienie się w jego istocie. Dlatego pozostanie on już zawsze niepełny, wewnętrznie pęknięty i targany sprzecznościami skończonego uniwersum. Ten spekulatywny Bóg jako negatywność jest dla Hegla absolutną obecnościa - staje się jawny dla siebie w czasie przez objawienie się w świecie. Ale co zostaje samo-objawione? Bóg jako pustka, to znaczy, że objawienie jest odsłonięciem się Boga przed samym sobą jako ogołoconego ze swojej

20 Najprościej rzecz ujmując, Heglowski sylogizm składa się z trzech momentów: dwóch terminów skrajnych i jednego terminu średniego będącego zapośredniczeniem tamtych. I tak w pierwszym sylogizmie istnienia (inaczej nazywanego jakościowym) mamy termin skerajny jednostkowości (J), termin średni sz̧czegótowości (S) i termin skerajny ogólności (O). Opracowanie tej skomplikowanej i technicznej procedury wnioskowania sylogistycznego zob. Hegel 1990, 213-226/\$181-193.

21 Heglowska teologia całkowicie redukuje źródłową omnipotencję Ojca, żydowskiego Boga radykalnej transcendencji. To wymazanie Ojca znakomicie potwierdza bardzo symptomatyczny lapsus Hegla (na który w tym kontekście powołują się zarówno Malabou, jak i Žižek): rekonstruując różnice doktrynalne pomiędzy Wschodnim a Zachodnim chrześcijaństwem dotyczące pochodzenia Ducha Świętego, filozof pomylił się, zamiast napisać, że w Kościele Wschodnim Duch Święty pochodzi od Ojca, natomiast w Kościele Zachodnim od Ojca i Syna, napisał: ,jeśli Duch Święty pochodzi od Syna, albo od Ojca i Syna [ob der Geist vom Sobne, oder vom Vater und Sohn ausgehe], to Syn jest tylko tym, który urzeczywistnia i objawia go - więc z niego samego pochodzi Duch" (fragment nie występuje w polskim wydaniu tekstu, pojawia się w niemieckim wydaniu z którego korzysta angielskie i francuskie tłumaczenie Wykładów - opracowanym przez Waltera Jaeschke, zob. Hegel 1995, 23).

22 Ból jest doznaniem, przez które Chrystus może doświadczyć swojej jednostkowości, ponieważ jednostkowość jest niczym innym jak bólem podmiotu oddzielonego od ogólnej substancji - jest cierpieniem płynącym z wyobcowania, w którym jaźń może dopiero poczuć się sobą (siebie w istocie tracąc). Jak zauważa Jean-Luc Nancy, bliski tutaj intuicjom Theodora Adorno: „Ból jest, mówiąc wprost, elementem jednostkowości oddzielenia, ponieważ za sprawą jednostkowości i jako jednostkowość ból powstaje”, a następnie dodaje, „doznanie bólu jest zatem odczuciem siebie w swojej jednostkowości” (Nancy 2002, 41). 
istoty, wydrążonego ze zdolności kreacji i nieskończonych mocy. W takiej nędzy objawia się swoim wyznawcom - „świadomości nieszczęśliwej” - którzy doświadczają wówczas „utraty wszelkiej istotności w tej pewności siebie i utraty właśnie tej wiedzy o sobie - zarówno substancji, jak i jaźni; [utrata ta - przyp. BW] jest bólem, którego wyrazem jest twarde słowo, że Bóg umarl' (Hegel 2002, 473).

Dlatego Malabou odczytuje Heglowską ideę parousia - absolutne uobecnienie się Boga w stworzeniu (jego obecność „dla siebie”) - jako współprzynależną z ideą źródłowej pasywności Boga, czyli jego podporządkowania się negatywności, która jest warunkiem konstytutywnym tak dla niego samego, jak i dla wszelkiej podmiotowości (zob. Malabou 2006, 84). Pasywność oznacza w tym kontekście także „czułość” Boga, jego podatność na działanie sił niezależnych od niego - w tak zradykalizowany sposób filozofka interpretuje zdanie Orygenesa, że „Bóg ojciec nie jest nieczuły [impassible]” (Malabou 2006, 85). Cały paradoks, w jaki uwikłany jest Bóg w „Religii objawionej”, polega na tym, że wyobcowując się od siebie, przybiera on formę podmiotowa, która to forma pochodzi właśnie od Bogaabsolutu jako matrycy subiektywności. W tym sensie nieograniczony Bóg, żeby stać się sobą, musi wyobcować się od siebie, musi przyjąć postać wyzewnętrznionego ograniczonego podmiotu (skończonego człowieka), który jest momentem jego samorozwoju. Bóg rozwija się w dialektycznym ruchu zwijania się, czyli nieustannie ogranicza samego siebie. Boskie samoograniczanie czy wyobcowanie jest dwuznaczne, ponieważ jest jednocześnie zewnętrzne (heteronomiczna wobec Boga moc negatywności) i samorzutne (Bóg wypuszcza z siebie podmiot jako swoja wyobcowaną postać, w której się rozpoznaje). Napięcie to, generowane przez bieguny autonomii i heteronomii, czyli heautonomii ${ }^{23}$, pozwala Malabou powiązać Boga z plastycznością. Jak twierdzi autorka:

\begin{abstract}
Oczywiście pojęcie pasywności nie jest samo w sobie wystarczające do opisania tego podwójnego aspektu. Dlatego musimy powrócić do pojęcia plastyczności w jego podwójnym znaczeniu przyjmowania i nadawania formy. Przykładem źródłowej syntetycznej jedności, która udziela się wszystkiemu co przez nią stworzone, jest podmiotowość Boga, która z perspektywy plastyczności jawi się nie jako absolutna
\end{abstract}

\footnotetext{
23 Pojęcia heautonomii używam tutaj za Marcinem Pańkówem, który ów Kantowski termin z Krytyki władzy sqązenia (z „Analityki piękna”) wykłada jako kategorię antycypującą ontologiczną formę intersubiektywności z Nauki logiki Hegla. Termin heautonomia oznacza pewną nową, pośrednią postać refleksyjności, która jednoczy autonomiczny proces samookreślenia z określeniem przez to, co heteronomiczne, a ufundowana jest w spontanicznej pasywno-aktywnej grze wyobraźni. „Hipoteza główna - pisze Pańków - dotycząca Heglowskiej koncepcji intersubiektywności brzmi: powiqzanie idei heautonomii i teorii wyobraźni przejetej od Fichtego otwiera przed Schillerem nowa perspektywe filozoficz̨na - umożliwia pomyślenie nowego typu "granicznego«, dystansujacego samookréślenia podmiotu. Perspektywa ta pozwala stworzyć nowe pojecie wolności, odrębne względem praktycznych idei Kanta i Fichtego" (Pańków 2012, 45). Schillerowska estetyczna idea wolności jako heautonomii zostaje rozwinięta w Heglowskiej Logice, ponieważ zyskuje w niej wymiar ontologiczny, dzięki czemu w pełni wyzwala się jej intersubiektywny (i polityczny) potencjał (zob. Pańków 2012, 59).
} 
obecność, będąca paradoksalnie pusta w stosunku do siebie, lecz jako żywe źródło procesu ucrasowienia (Malabou 2006, 84).

Bóg jest plastycznością, dialektycznym splotem negatywności i pozytywności, aktywności i pasywności, podmiotowości i przedmiotowości, czyli spekulatywną tożsamością dwóch końców: ostatecznego i odroczonego. W tę podwójną logikę kończenia Boga wpisuje się również jego śmierć na krzyżu, która jest także śmiercia podwójną, tzn. dwóch natur Boga: boskiej i ludzkiej. Na krzyżu umiera nie tylko Chrystus - ziemskie wcielenie Boga lecz sam transcendentny Bóg-w-sobie. Ta radykalnie heterodoksyjna wykładnia „śmieci Boga” stanowi klucz do interpretacji chrześcijańskiej a-teologii Hegla, dlatego należy uważnie się jej przyjrzeć.

4.

Pod koniec rozdziału „Królestwo Syna” w Wykładach z filozofii religii czytamy:

\begin{abstract}
Bóg przejawił się jako człowiek; to człowieczeństwo w Bogu, i to w najbardziej abstrakcyjnej postaci, ta najwyższa zależność, największa słabość i największy stopień kruchości - to właśnie naturalna śmierć. „Sam Bóg umarl” - takimi stowami uyraża to ow $a^{24}$ luterańska pieśn; ta świadomośc nyraża to tak, że to, co ludzkie, skończone, kruche, słabość, to, co negatywne, jest boskim momentem, jest w samym Bogu; to, że innobyt, to, co skończone, to, co negatywne, nie jest poza Bogiem, jako innobyt nie przeszkadza jedności z Bogiem. Innobyt, negacje zna się jako moment samej boskiej natury (Hegel 2006b, 315; podkr. BW).
\end{abstract}

Natomiast we wczesnym tekście (Glauben und Wissen z 1802 roku) Hegel napisał: „uczucie, że sam Bóg umarł jest podstawa, na której opieraja się religie czasów współczesnych” (zob. Malabou 2006, 103). Radykalna idea, że „Bóg sam umiera”, że śmierć jest konstytutywnym momentem jego istoty, jego wewnętrzną samo-negacją, została w swojej teoretycznej doniosłości po raz pierwszy wyrażona właśnie przez Hegla. Malabou twierdzi, że śmierć Boga jako manifestacja jego prawdy stanowi fundamentalną tezę całej spekulatywnej filozofii religii (zob. Malabou 2006, 105). Uśmiercenie Boga przez samego siebie i dla samego siebie nie jest abstrakcyjną śmiercią, wyzerowującym końcem, który ostatecznie unicestwia boskość,

\footnotetext{
24 Słowa „Gott selbst ist tot” („Sam Bóg umarł”) pojawiły się w napisanej przez Johanna Rista w 1641 roku drugiej zwrotce pieśni pasyjnej O Traurigkeit, O Herzeleid, do której muzykę skomponował Jan Sebastian Bach.
} 
lecz właśnie śmiercią zniesioną - opanowaną i włączoną w nieskończony ruch boskiego samo-określania się, które dokonuje się za pośrednictwem swoich momentów. Nie jest negatywnością Boga pochłaniająca, ale negatywnością w Bogu - czyli jego plastycznością (już zapośredniczoną i wzajemnie odniesioną do siebie relacją obu końców: złego i dobrego albo po prostu zniesieniem śmierci-końca w nieskończonej-idei). Ta immanentna Bogu śmiertelność-skończoność, jego wewnętrzna kruchość i słabość jest także miejscem najintymniejszej bliskości tego, co boskie z tym, co ludzkie - jest dialektyczną tożsamością Boga i człowieka.

Spekulatywna gnoza Hegla ${ }^{25}$, w której Bóg umiera, by pojednać się z kalekim i niedoskonałym stworzeniem, zostanie w radykalnie ateistycznym - i ostatecznie antygnostyckim - duchu odczytana przez Žižka. Według słoweńskiego filozofa w chrześcijaństwie Bóg umiera dla siebie, co ma dwojakie konsekwencje: śmierć samego Boga jest warunkiem przejścia od jego bytu-w-sobie (transcendentnej substancji) do jego bytu-dlasiebie (podmiotu bez transcendencji); oraz, co bardziej zaskakujące, Bóg przestaje wierzyć już w samego siebie. „Jeśli we wszystkich innych religiach to ludzie nie wierzą w Boga, to tylko w chrześcijaństwie Bóg nie wierzy w samego siebie” (Žižek 2009, 49), co oznacza, że sam Bóg jest ateistą! Taki jest ostateczny sens najważniejszych słów, które padają w Biblii, tj. ostatnich słów Chrystusa umierającego na krzyżu: „Eli, Eli, lema sabachthani?” („Boże mój, Boże mój czemuś mnie opuścił”? Mt 27, 46). Bóg ukrzyżowany i oczekujący śmierci doprowadza do logicznego końca proces objawienia - objawia samemu sobie, że Boga nie ma, wyzbywa się swojej boskości by w pełni móc się zjednać z człowiekiem² ${ }^{26}$. Ten akt boskiego samo-ofiarowania uśmierca „tamtą stronę” (Jenseits), transcendentne Zaświaty,

25 Światosław Florian Nowicki określił teologię Hegla mianem spekulatywnej gnozy, w której pojęciowe poznanie absolutu jest możliwe tylko na gruncie przyjętych zasad filozofii spekulatywnej. Badanie związków Hegla z tradycją gnostycką i myślą hermetyczna - przeprowadzone w iście detektywistycznym stylu - stanowi przedmiot kontrowersyjnej rozprawy Glenna Alexandra Magee, Hegel and the Hermetic Tradition (Magee 2001). Problem tego podejścia, które reprezentuje także Nowicki, polega głównie na tym, że z korelacji pewnych motywów, pojęć, metafor czy problemów pomiędzy Heglem i gnozą wyciaga się zbyt daleko idące wnioski. Nie dopuszcza się możliwości, że Hegel mógł ironicznie traktować te powiązania i bawić się nimi, podobnie jak czynił w odniesieniu do innych dyskursów silnie obecnych w jego środowisku (np. frenologii). Swoją drogą podział na gnostyckie (Nowicki, Magge) i ateistyczne interpretacje (Kojève, Žižek) filozofii religii Hegla odtwarza dawny konflikt między prawicą i lewicą heglowską.

26 Ten perwersyjny, ateistyczny rdzeń chrześcijaństwa odsłonięty przez Hegla (śmierć na krzyżu samego transcendentnego Boga) wyraża w gruncie rzeczy to, co dla Žižka jest centralną koncepcją Mistrza Eckharta, tzn. „eks-centryczność samego Boga, ze względu na którą Bóg potrzebuje człowieka, by stać się soba, urzeczywistnić siebie, dlatego Bóg rodzi się w człowieku, a człowiek jest przyczyną Boga” (Žižek 2009, 33). U Eckharta Bóg jest ugruntowany w otchłannym Bóstwie (Gottheit) (Niebogu - zgodnie z Kantowskim sądem nieokreślonym), czyli jest Nicością. W Kazaniu 23 padają znamienne słowa: „A jeśli nie jest On ani dobrocia, ani bytem, ani prawdą, ani jednym, czymże zatem jest? - Nicością!” (Mistrz Eckhart 2013, 275). Śmierć Boga objawienie się nicości w nim - jest także odsłonięciem nicości samego człowieka, który staje wówczas naprzeciw negatywności i patrząc jej prosto w oczy, dostrzega, że Jest tylko Nic - ruch „od niczego, przez nic, do niczego", jakby to ujął Hegel. 
pozostawiając człowieka - czyli także Boga w ludzkim wcieleniu, Chrystusa - całkowicie osamotnionego wobec faktu śmierci.

Ojca nie ma, Syn jest człowiekiem, a Duch Święty wspólnotą miłości, która skończonego i ułomnego człowieka może uchronić przed „absolutyzmem rzeczywistości”. Bóg umierając, dokonuje radykalnego odczarowania świata, zdejmuje wszystkie zasłony i iluzje, samego siebie objawiając jako pozór. W tej powszechnej ułudzie człowiek zyskuje radykalną wolność - nie ma żadnej ogólnej instancji, której podlega, żadnego wielkiego Innego. Dlatego tylko czyny, ograniczonej i kruchej miłości bliźniego moga go ocalić - tak brzmi credo „dialektycznej Wielkiej Soboty” Žižka. By przywołać Hegla, „w negacji nieskończonego bólu miłości tkwi też dopiero możliwość i podstawa prawdziwie ogólnego prawa, urzeczywistnienia wolnoścl” (Hegel 2006b, 322).

Śmierć Boga obnaża ponadto antagonizm w jego pojęciu - wewnętrzny podział w nim samym. Bóg wcale nie jest wszystko obejmująca totalnościa, wielkim zbiornikiem pochłaniającym każdą partykularną treść, czy panteistyczną pełnią, w której zawiera się cały wszechświat. Žižek odnosząc Boga do Heglowskiej dialektycznej relacji ogólności i szczegółowości, zauważa, że różnica nie jest pomiędzy oboma biegunami, ale w samej ogólności, która jest niespójna, immanentnie sprzeczna i niedomknięta. Szczegółowość jest momentem samej ogólności, której wewnętrzny antagonizm bezskutecznie próbuje przekroczyć i pojednać. W kategoriach teologicznych można powiedzieć, że Bóg jest zepsuta, cierpiąca w „bólu negatywności” ogólnością, która stwarza szczegółowość (świat ludzki), aby ocalić siebie: stworzenie ma wówczas funkcję terapeutyczną. Jako takie ma na celu zakończenie szaleństwa cierpiącego Boga poprzez wypełnienie nieprzekraczalnej luki w nim samym, jednak w rzeczywistości - jak każda terapia - pozwala jedynie na przejście od „wielkiego nieszczęścia, do zwykłego cierpienia” niemającego końca ${ }^{27}$. Bóg jest „jednością przeciwieństw", nie tylko w sensie coincidentia oppositorum ${ }^{28}$ Mikołaja z Kuzy - jako „Wszytskojednia”, doskonałe połączenie Maksimum i Minimum czy Trójednia pojmowania, pojmującego i pojmowanego (zob. Mikołaj z Kuzy 1997, 55, 64, 101-103):

Hegel mówi o czymś znacznie bardziej radykalnym: ,jedność przeciwieństw” oznacza, że w refleksyjnie skierowanym do siebie krótkim spięciu Bóg upada w swoje własne

27 Skądinąd Hegel antycypuje ten etyczny wymiar psychoanalizy, pisząc o ponownych narodzinach człowieka w duchu, w których „nieskończony realny ból nie jest wprawdzie oszczędzony podmiotowi, ale jest załagodzony" (Hegel 2006b, 342).

${ }^{28}$ W kontekście Hegla (a już na pewno Hegla czytanego przez Žižka) mówienie o jedności przeciwieństw jako coincidentia oppositorium jest nie do końca adekwatne, na co ciekawie zwraca uwagę jeden z włoskich neoheglistów cytowanych przez Antonio Gramsciego w Zeszytach filozoficznych, niejaki Guido Calogero, pisząc: „Nieśmiertelną zdobyczą Hegla jest ustalenie jedności przeciwieństw, rozumianej nie w sensie statycznej i mistycznej coincidentia oppositorium, lecz w znaczeniu dynamicznej concordia discord"' (za: Gramsci 1991, 47-48). 
stworzenie; podobnie jak przysłowiowy wąż zjada swój własny ogon. Mówiąc krótko, „jedność przeciwieństw” nie znaczy, że Bóg bawi się ze sobą w grę (samo)wyobcowania, pozwalając na zło w celu pokonania go i tym samym potwierdzenia swojej moralnej siły itd.; oznacza ona, że „Bóg” jest maską (trawestacja) „Szatana”, że różnica między Dobrem i Złem jest wewnętrzna dla samego Zła (Žižek 2009,50).

Radykalna konkluzja Žižka (ewidentnie inspirowana jego czytaniem Hegla Eckhartem i Schellingiem) polega na pojmowaniu Boga jako „określenia refleksyjnego"29 Szatana, a Dobra jako wewnętrznego momentu, z którym zapośredniczone jest samo Zło ${ }^{30}$. Bóg chrześcijański nie jest zatem ani pogańskim Bogiem pokojowej harmonii, homeostatyczną Matką Ziemią regulującą i stabilizującą wszystkie przepływy energetyczne we Wszechświecie (Dobrem), ani starotestamentowym Bogiem niszczycielskim, arbitralną i kapryśną siła negatywności (Złem), ale Bogiem cierpiącym, który w akcie kenosis wyrzeka się siebie, uśmiercając się na krzyżu (jest paradoksalną ,jednością w różnicy” Dobra i Zła). Jego cierpienie Žižek łączy z najbardziej „cierpiącą” z Biblijnych postaci, czyli z Hiobem: „Śmierć Chrystusa na krzyżu jest śmiercią samego Boga, powtarza ona postawę Hioba, ponieważ odrzuca jakiekolwiek "głębsze znaczenie«, które tylko zaciemnia brutalną rzeczywistość historycznych katastrof' (Žižek 2009, 55). Hiob milczy nie dlatego, że jest przytłoczony boską obecnością czy na znak protestu wobec milczenia samego Boga, milczy, gdyż cicho solidaryzuje się z impotencją Boga. W przewrotnym odczytaniu Žižka, to sam Bóg najdotkliwiej doświadcza Hiobowych nieszczęść, ponieważ to on, a nie Hiob, został poddany próbie, w której całkowicie poległ, demaskując swoją bezsilność: „Hiob przewidział przyszłe cierpienie Boga - »Dzisiaj jestem ja, jutro będzie Twój syn i nie będzie już nikogo, kto przyjdzie $m u$ na ratunek. To co widzisz teraz jest prefiguracja Twojej własnej Pasjil«" (Žižek 2009, 56).

29 „Określenie refleksyjne” (Reflexionsbestimmung) to kluczowy termin Heglowskiej logiki refleksji, który zdefiniowano w „Nauce o istocie”. „Określenie refleksyjne - pisze Hegel - jest więc założonościa, negacja, ale jako refleksja w sobie jest ono zarazem zniesieniem założoności, nieskończonym odnoszeniem się do siebie" (Hegel 2011b, 33). W niniejszym kontekście Szatan byłby z jednej strony założonościa, negacją, która swoje odnoszenie się do ,innego” (Bóg) zawraca w samą siebie (Bóg jako wewnętrzny moment Szatana), lecz z drugiej strony negacja jest tożsama ze soba, gdy jest jednością siebie i swojego „innego” (jedność Szatana i Boga) - wtedy tylko jest istotnością. Bóg jako „określenie refleksyjne Szatana” oznacza ni mniej, ni więcej fakt, iż Bóg jest odnoszeniem się do Szatana w ramach samego Szatana. Jeszcze inaczej można stwierdzić, że Szatan stwarza innego-Boga, który działa zamiast niego, w jego zastępstwie: aktywność Boga jest nie tylko określana przez refleksję Szatana (wtedy pozostawalibyśmy na poziomie refleksji określającej, czyli dialektycznej jedności ustanawiania i refleksji zewnętrznej), lecz ustanawiana jako jego określenie refleksyjne.

${ }^{30} \mathrm{O}$ złu jako przesłance dobra Hegel pisze np. w jednym z fragmentów Wykładón z filozofii religii: „Bycie złym abstrakcyjnie biorąc, oznacza ujednostkowienie siebie; ujednostkowienie, które się oddziela od tego, co ogólne; tym [, co ogólne] jest to, co rozumne, prawa, określenia ducha [tzn. dobro - przyp. BW]. Ale wraz z tym rozdzieleniem powstaje byt dla siebie i dopiero [wtedy, powstaje] to, co ogólne, duchowe, prawo, to, co być powinno" (Hegel 2006b, 272). 
Heglowska lekcja śmierci Chrystusa na krzyżu polega na totalnym odczarowaniu świata, na jego demitologizacji i descendencji, na konfrontacji z nieuchronnością skończoności, na śmierci właśnie jako nieprzekraczalnym kresie, co tylko ponownie wiąże doświadczenie boskiego podmiotu i nowoczesnej jaźni stojącej na progu rozdarcia nowej epoki. Rozdarcia, o którym można najogólniej powiedzieć, że polegało na rozpoznaniu kluczowych sprzeczności rozwijającego się nowoczesnego mieszczańskiego społeczeństwa kapitalistycznego (w tym, rozdźwięku immanentnemu zajmowanej pozycji krytycznej). Jak trafnie zauważył Lukács:

\begin{abstract}
W ten oto sposób wybitni humaniści mieszczańscy Niemiec stają w obliczu złożonej i wewnętrznie sprzecznej konieczności: z jednej strony muszą uznać to burżuazyjne społeczeństwo, musza je afirmować jako konieczna, jedynie możliwą i postępowa rzeczywistość, z drugiej zaś muszą krytycznie ujawniać i wypowiadać jego sprzeczności, jeśli nie chcą być apologetami i kapitulować przed nieludzkim charakterem tego społeczeństwa. Sposób, w jaki sprzeczności te próbuje dostrzec i rozwiązać klasyczna filozofia i literatura niemiecka [...] świadczy o jej powszechnodziejowej wielkości, a zarazem o jej ograniczeniach, które wypływają z mieszczańskich horyzontów w ogóle, a z „niemieckiej mizerii” w szczególności (Lukács 1980, 198 199).
\end{abstract}

Możemy dodać, że Bóg Hegla również cierpiał na ograniczenie spowodowane „niemiecką mizerią" (tak dobitnie przez Marksa wykazana). Stanowi to także ostateczny dowód przeciwko rzekomej gnozie Hegla - nie ma żadnej wyższej, doskonałej realnej pełni-absolutu (pleromy), która zostałaby utracona wraz z pojawieniem się świata, czyli upadkiem w materialne stworzenie. Ponieważ Bóg jest tak samo „wykolejony” jak rzeczywistość obwieszczająca jego nieistnienie.

W tej rozdartej i kryzysowej nowoczesności nie ma już „wielkiego Innego” jako transcendentnej i ostatecznej gwarancji sensu, jesteśmy sami, zdani tylko na siebie ${ }^{31}$. Co znaczy także, że nie ma żadnego teleologicznego końca końców, który nadejdzie i rozwiąże sprzeczności, napięcia i cierpienia, jakich doznajemy w codziennej komunikacji

31 Žižek wnioskiem tym kończy Kukłe i Karla: „Gdy umiera Chrystus, tym, co umiera wraz nim jest sekretna nadzieja, którą dostrzec można w »Ojcze, dlaczegoś mnie opuścił?«; nadzieja, że jest pewien ojciec, który mnie porzucił. „Duch Święty« jest społecznościa pozbawioną swojego oparcia w wielkim Innym. Sedno chrześcijaństwa jako religii ateistycznej nie polega na wulgarnym humanizmie, zgodnie z którym boskie stawanie-się-człowiekiem objawia to, iż tajemnicą Boga jest człowiek (Feuerbach i in.) Atakuje ono raczej religijny twardy rdzeń, który utrzymuje się nawet w humanizmie, nawet aż do stalinizmu, rdzeń odznaczający się wiarą w Historię jako »wielkiego Innego«, który decyduje o »obiektywnym sensie» naszych dokonań« (Žižek 2006, 220-221). 
pośredniej i radykalnie przygodnym uniwersum, ponieważ problemy i przeszkody napotykane przez nas, są końcem bez końca, my zaś nieudolnie próbujemy je przezwyciężać (choć wtedy de facto już je przepracowujemy i tym samym oswajamy) kierowani nadzieja na ten ostateczny koniec, wielki finał - zbawienie.

\section{5.}

Podsumujmy fundamentalny dla rozważań o końcu religii problem „śmierci samego Boga” na podstawie interpretacji ukrzyżowania Chrystusa z Heglowskich Wykładów z filozofii religii:

Bóg umarł, bóg jest martwy - jest to najstraszniejsza myśl, że wszystko co wieczne, wszystko co najważniejsze nie istnieje, że $w$ Bogu jest sama negacja; wiąże się z tym najwyższy ból, poczucie całkowitej beznadziejności, rezygnacja ze wszystkiego co wyższe (Hegel 2006b, 308).

Z powyższego opisu wyłania się zły koniec, nie jako telos i ostatecznie pojednanie (o którym była mowa przed chwila), tylko jako zerwanie, uwolnienie abstrakcyjnej mocy śmierci jako siły totalnego unicestwienia ducha. Śmierć Boga byłaby triumfem czystej negatywności, apokalipsą odsłaniającą absolutną pustkę bytu. Jednak już w następnym zdaniu Hegel reflektuje się, albowiem:

na tym bieg spraw się nie zatrzymuje, lecz następuje teraz odwrócenie [Umkeehrung]; mianowicie Bóg zachownje sie $\mathrm{w}$ tym procesie, a tym [procesem] jest tylko śmierć śmierci [der Tod des Todes]. Bóg powstaje na nowo do życia: obraca się to więc w przeciwieństwo [...]. Ale śmierć Chrystusa jest śmiercią samej tej śmierci, negacja negacji $[\ldots]$. W śmierci Chrystusa, na koniec jest uwydatniony jeszcze ten moment, że Bóg uśmiercił śmierć, skoro wyszedł z niej [żywy];[...] (Hegel 2006b, 308-310).

Bóg umierając, uśmierca samą śmierć32 - niejako unieczynnia czy zawiesza śmiertelność śmierci - zachowując siebie po śmierci. Innymi słowy, doprowadza koniec do jego końca, czyli przekracza koniec, koniec ten jednak zachowując jako swój moment - koniec staje się

\footnotetext{
32 Malabou w swoim komentarzu zauważa: „Wyrażenie »mors mortis« występuje wielokrotnie w pismach Lutra, wyjątkowość tej Heglowskiej wersji odznacza się w sposobie, w jaki intepretuje on tę śmierć śmierci jako »negację negacji«. Na podstawie takiej wykładni możemy już antycypować przejście od teologicznego znaczenia kenosis do jej sensu filozoficznego" (Malabou 2006, 107).
} 
nieustającym kończeniem, dobrym końcem bez końca. Ów zły koniec kończący dialektycznie zapośrednicza się z dobrym końcem niekończącym: Chrystus umiera a wraz z nim umiera sama śmierć, dokonuje się negacja negacji. Ba, to sam „Bóg jest - pisze Mistrz Eckhart - Jednym i negacją negacji” (Mistrz Eckhart 2013, 260).

Nie należy tego wulgarnie odczytywać, jakoby śmierć wcale nie była końcem, ponieważ czeka nas po niej życie wieczne, że dzięki odkupieniu przez Chrystusa człowiek jest ponad śmiercią, gdyż ona jest tylko etapem na drodze do zbawienia przychodzącego z Zaświatów itd. Dla Hegla zbawienie już się dokonało, tu i teraz, w doczesności, jak w znamiennym fragmencie z apokryficznej ewangelii Tomasza: „Spytali Go uczniowie Jego: »W którym dniu nastanie odpocznienie zmarłych i którego dnia nastanie nowy świat?«. Odrzekł im: »To, czego wyczekujecie, nadeszło, ale wy tego nie widzicie«" (Ewangelia Tomasza 1986, 128). W podobnym duchu należy odczytywać przytaczane przez Hegla słowa Chrystusa „Nie biegajcie to tu, to tam, Królestwo boże jest w was” (Łk 17,21) (Por. Hegel 2006b, 329). Działa tutaj Heglowska logika „negacji negacji”, która polega na zmianie (odwróceniu) podmiotowego usytuowania ${ }^{33}$. Gdyby odnieść ja do analizowanego fragmentu, to sprawa wyglądałaby następująco: (1) pierwsza negacja to zły koniec - śmierć Boga jako radykalny nihilizm (nie ma niczego, a człowiek pogrążony jest w otchłannym lęku); (2) druga negacja to po prostu dobry koniec, a nie żaden nowy początek (powrót do pierwszej negacji z odwróconym wektorem). Jak to rozumieć?

To, co jawiło się jako największe przerażanie - brak instancji „wielkiego Innego” scalającego pole symboliczne, czyli puste miejsce po martwym Bogu - okazuje się faktycznym zbawieniem, uśmierceniem śmierci. Człowiek przeżył śmierć dlatego, że zaakceptował ja jako

33 W celu właściwego zrozumienia formuły „negacji negacji” warto sięgnąć do przykładu Žižka ze Wrniosłego obiektu ideologii, w którym przywołuje on radziecki dowcip o Rabinowiczu, Żydzie zamierzającym wyemigrować z „Kraju Rad”. Urzędnik w biurze emigracyjnym pyta go o powody jego wyjazdu. Rabinowicz odpowiada mu: „»Są dwa powody po temu. Pierwszy to taki, że obawiam się, iż komuniści w Związku Radzieckim stracą władzę, wybuchnie kontrrewolucja i nowa władza obciąży nas, Żydów, winą za wszystkie zbrodnie komunizmu - znowu więc zaczną się antysemickie pogromy...«. »Ale - przerywa mu urzędnik to czysty nonsens, nic nie może się zmienić w Związku Radzieckim, władza komunistyczna będzie trwać wiecznie!«. »To prawda - odpowiada spokojnie Rabinowicz - i to jest właśnie ten drugi powód «" (Žižek 2001,208). Dowcip ten znakomicie inscenizuje logikę heglowskiej triady: jeśli pierwszy powód byłby tezą, a uwaga biurokraty antytezą, to synteza nie byłaby żadnym powrotem do wyjściowego stanowiska, lecz powtórzeniem antytezy z przeciwnym wektorem - to znaczy ze zmieniona perspektywą. To, co występowało jako przeszkoda - argument przeciwko emigracji - staję się warunkiem pozytywnym, prawdziwym powodem wyjazdu Rabinowicza. Aufhebung nie jest żadnym ustanowieniem totalnej tożsamości, statycznym elementem syntezującym i zamykającym w uspokojonej w-sobie substancjalności, absolutną synteza. Zniesienie ma strukturę dynamiczna, jest permanentnym ruchem znoszenia - nieredukowalnym napięciem tego, co negatywne (wkradającego się nieustannie w bezpieczny obszar tożsamości). Zniesienie wreszcie, jak zauważa Žižek za Heglem, ma strukturę „negacji negacji”, której nie należy rozumieć jako powrotu do wyjściowej pozytywnej tożsamości niwelującej całą moc negatywności: logika ta nie rządzi się prawem klasycznego rachunku zdań, w którym złożenie dwóch negacji daje w konsekwencji przekształcenie identycznościowe. Dzieje się tutaj coś zgoła odmiennego: negatywność, destrukcyjna siła rozbijająca tożsamość (uniemożliwiająca jej domknięcie) jest jej warunkiem pozytywnym, tym, co ją w ogóle umożliwia. 
jego najgłębszą, nieredukowalną istotę, zniósł śmierć jako koniec końców w śmierci jako końcu bez końca - skończonym horyzoncie umożliwiającym prace samo-określania się jaźni:

\begin{abstract}
Ale przezwyciężenie tego, co negatywne - czytamy w dopisku Hegla z roku 1821 nie jest odejściem od ludzkiej natury, lecz jej najuyżssym potwierdzeniem w śmierci i w najuy isszej mitości. Duch jest duchem tylko jako to, co negatywne [w stosunku do] tego, co negatywne, tym samym zawiera więc w sobie to, co negatywne (Hegel 2006b, 309; podkr. BW).
\end{abstract}

Śmierć pozostała, zmieniła się tylko jej funkcja (a raczej modalność końca, który ja obsługuje), Chrystus na krzyżu objawił człowiekowi prawdę o nim samym, że jest śmiertelny i ma w sobie swój koniec - że jest bez-gruntem (Abgrund), czystym „ja”, do którego sprowadza się wszelka obiektywna treść. „Przeznaczeniem ludzkiej skończoności jest umrzeć; w ten sposób śmierć jest najwyższym dowodem człowieczeństwa, absolutnej skończoności” (Hegel 2006b, 306). Dopiero ta świadomość otwiera drogę do samowiedzy, a pogodne zaakceptowanie swojej skończoności i nienaprawialności umożliwia dopiero budowanie kruchej - pozbawionej jakichkolwiek trwałych fundamentów - wspólnoty (Ducha Świętego) opartej tylko na przygodnych i efemerycznych dziełach miłości ${ }^{34}$, czyli solidarnej i wzajemnej współpracy pomiędzy podmiotami ${ }^{35}$. Dla Hegla ta nowa wspólnota, nowe królestwo może się urzeczywistnić tylko dzięki „rewolucyjnej mocy” śmierci Chrystusa na krzyżu, przez którą świat otrzymuje całkiem nową postać. Krzyż jest symbolem odwrócenia (Umkherung), czyli promiennego przemienienia (verklärt) tego, co w sensie społecznym najbardziej zhańbione (ukrzyżowanie złoczyńcy), w to, co najbardziej chwalebne (sztandar przyszłego Królestwa Bożego). W wyniku tej rewolucyjnej interwencji życie obywatelskie i państwowe

\footnotetext{
${ }^{34} \mathrm{O}$ śmierci jako podstawie miłości Hegel pisze patetycznie: „Haniebna śmierć jako monstrualne zjednoczৃenie tych absolutnych kerańcowości [Boga i skończoności - przyp. BW] jest tu zarazem nieskończonq mitościa”" (Hegel 2006b, 310).

35 Zdaniem Žižka Hegel w ten sposób antycypuje to, co Lacan określi mianem zawieszenia funkcji Pana, zniesieniem wielkiego Innego (jako ostatecznego gwaranta, że jest jakiś koniec końców), które nie skutkuje wcale triumfem wyobcowanych i stłumionych ludzkich mocy produktywnych (jak proponowałaby ideologia humanistyczna - człowiek się wyzwolił od religijnej alienacji i stał się w pełni soba), tylko czymś zgoła odwrotnym - doświadczeniem całkowitego rozpadu współrzędnych porządku symbolicznego (radykalnej dezintegracji wspólnoty). „Pojmowana w ten sposób, »śmierć Boga« nie może być już doświadczeniem wyzwalającym, odwrotem Zaświatów [Jenseites - przyp. BW], który daje człowiekowi wolność, otwierając przed nim dziedzinę ziemskiego działania, obszar, na którym ma utwierdzać swoją twórczą podmiotowość. »Śmierć Boga« wiąże się raczej z utratą spójnej »ziemskiej« rzeczywistości. »Śmierć Boga« nie zapowiada triumfu autonomicznych, twórczych zdolności człowieka, jest bliżej spokrewniona z tym, co wybitne teksty mistyków określają z reguły jako »noc świata«: rozpad symbolicznie stworzonej rzeczywistości” (Žižek 2013, 65).
} 
„traci swoją substancjalną podstawę, tak, że cała budowla [państwa] nie ma już rzeczywistości, lecz jest pustym zjawiskiem, które wkrótce z trzaskiem musi runąć, i to, że samo w sobie nie istnieje, musi zamanifestować się również w istnieniu" (Hegel 2006b, 308).

\title{
6.
}

Dochodzimy tym samym do intersubiektywnego, konkretnego i materialnego wymiaru tych teologicznych spekulacji. Dla Malabou nowoczesne pojęcie plastyczności należy rozumieć jako ruch samo-określania, w którym same przypadłości stają się tym, co istotowe: boskie wcielenie jest exemplum tego procesu:

\begin{abstract}
Kenosis - pisze autorka - to ruch, poprzez który Bóg, ustanawiając siebie w zewnętrzności i stając się swoim innym, osiaga spełnienie swojego bytu i staje się zarazem predykatem i przypadłością. Znajdujemy tutaj nowoczesne znaczenie podmiotowości, które cechuje relacyjne odnoszenie się podmiotowych form do siebie nawzajem poprzez zapośredniczenie się ze swoim innym (Malabou 2006, 119).
\end{abstract}

W tym sensie w boskiej kenosis manifestuje się nowoczesna forma podmiotowości, która konstytuuje się $\mathrm{w}$ ramach intersubiektywnych sieci relacji z innymi uczestnikami pola społecznego. Stawanie się soba jest nieskończonym, uczasowionym procesem polegającym na nieustającym wyzewnętrznianiu się, refleksyjnym odnoszeniu się do tego, co inne. Będąc istotami określonymi w czasie, sobą jesteśmy tylko poza sobą. Tak też należy rozumieć spekulatywną definicję miłości - jako pełne uznanie, że moja egzystencja zależy od innego.

Dlatego zarówno dla Malabou, jak i dla Žižka konsekwencją boskiego wyobcowania się poprzez wcielenie w skończonym świecie doczesnym jest to, że „Bóg objawia ludzkości czasowość bytu [...]. Wyobcowanie jest idea, która jest bezsprzecznie nowoczesna, a czasowość przypomina skończoność zjawiskowego podmiotu” (Malabou 2006, 113). Podkreślmy po raz kolejny to kluczowe rozpoznanie: sam Bóg umierając na krzyżu, objawia człowiekowi czasowy, a więc skończony charakter jego bytu, pozbawiając go wszelkiego poza-światowego oparcia. Teologiczna kenosis zbiega się z filozoficzną kenosis. Nowoczesna (post-metafizyczna) świadomość - ogołocona z substancjalnego ugruntowania, wyzbyta wszelkiej treści i odarta z tożsamości- okazuje się czysto formalną pustką samo-odniesienia. W tym punkcie Malabou kończy swoją interpretację pojęcia religii, której celem była ekspozycja plastyczności Heglowskiego Boga znajdującego się na „skrzyżowaniu czasów” starożytności i nowożytności, cykliczności i linearności. Dlatego nowoczesna podmiotowość 
powstała po kenotycznym procesie tworzenia i znoszenia boskiej reprezentacji w ludzkim elemencie (wcielenie i śmierć Chrystusa) jest uwikłana w dwuznaczność samego czasu: skończone indywiduum jest jednocześnie niespełnione, wyeksterioryzowane z substancjalnej pełni wciąż antycypuje swojego wypełnienie. A samo to „kryterium spełnienia zakładane przez nowoczesność musi w istocie pochodzić z czasu, który nie jest nowoczesny - z czasu teleologicznego wypełnienia, gdzie koniec jest tożsamy z początkiem” (Malabou 2006, 130). Pozostawiony samemu sobie do bólu skończony podmiot oczekuje jakiegoś mesjańskiego finału, ostatecznego rozstrzygnięcia - „czasu, który nadejdzie”. Dla Malabou w tej fantazji o zbawczym końcu końców, z którą pozostawia nas martwy Bóg, otwiera się Heglowska przyszłość ${ }^{36}$.

Natomiast wyzbyty mesjańskich nadziei Žižek ujmuje „kenozę” jako inna nazwę „podmiotowej destytucji” (będącej końcem terapii psychoanalitycznej), która:

\begin{abstract}
zmusza Pana [Boga, podmiot metafizyczny, czyli wielkiego Innego - przyp. BW], żeby zauważył, że z definicji podaje się za kogoś, kim nie jest, że jest idiotą, który widzi skutki swoich decyzji $\mathrm{w}$ tym, co faktycznie wynika $\mathrm{z}$ automatycznego biegu maszyny symbolicznej. Koniec końców dotyczy to każdego podmiotu. [...] terapia psychoanalityczna dobiega końca, gdy podmiot przestaje się obawiać i swobodnie akceptuje własne nieistnienie (Žižek 2013, 247).
\end{abstract}

Jeśli podmiot zaakceptuje własne nieistnienie - pustkę-w-sobie, którą jest, wydrążone miejsce po nigdy nieobecnej treści - to jak może odroczyć pogrążenie się w złym końcu, całkowite rozpuszczenie się w uwolnionej i rozpanoszonej negatywności, która go pochłonie i nic po nim nie pozostawi? Jak można w tej nieuchronnej perspektywie (samo)destrukcyjnego końca kończącego wprowadzić ruch przeciwstawny jednoznacznej i jednostronnej negacji, czyli dobry koniec, koniec powstrzymujący? Gdzie, w jakiej przestrzeni można uruchomić grę wzajemnego, zapośredniczającego odnoszenia się do siebie obu tych końców?

Oczywiście odpowiedzią jest Duch Święty! To w nim zostają zniesieni Bóg ziemski i Bóg transcendentny, a także zły i dobry koniec. Nie jest on żadną nową formą domkniętej i tożsamej-w-sobie, absolutnej substancji, jakąś kończącą supertożsamościa, która

36 Jak słusznie zauważył recenzent niniejszego tekstu, zaklasyfikowanie Malabou do partii mesjanistów jest bardziej problematyczne, zwłaszcza zważywszy na jej późniejsze publikacje. Problem mesjanizmu wraca chociażby w Ontologii prazpadłości, gdzie mamy do czynienia z w istocie anty-mesjańskim przesłaniem: „To nieprawda, że struktura obietnicy jest niedekonstruowalna. Filozofia, która nadchodzi, musi poddać eksploracji przestrzeń tej porażki struktur mesjanistycznych” (Malabou 2017, 141). Jednak na etapie L'Avenir de Hegel Malabou nie przepracowuje porażki struktur mesjanistycznych, albowiem jej myślenie operuje jeszcze w ich ramach - być może dlatego nie potrafi dostrzec u samego Hegla wzorcowej „eksploracji przestrzeni” tej mesjańskiej porażki. 
przezwycięża w sobie różnice i antagonizmy. Duch Święty jest nieskończonym bytem wirtualnym, który utrzymuje się dzięki pracy podmiotów zachowujących się tak, jakby istniał37. To znaczy, że przesłanka jego istnienia jest działanie zakładanych przez niego elementów: choć zniesiony (uśmiercony na krzyżu) Bóg powraca (zmartwychwstaje) we wspólnocie wiernych, to tak naprawdę dopiero ta wspólnota go ustanowiła. Wspólnota wiernych stworzyła transcendentnego Boga jako swoją podstawę, dzięki której zyskała minimalną spoistość umożliwiająca jej właściwe funkcjonowanie: gmina chrześcijańska antycypacja nowoczesnego ducha obiektywnego - istnieje dzięki działaniu wiary, która jest zawsze samozwrotna (wierzyć w coś, oznacza wierzyć w samą wiarę). Co zresztą zauważa Hegel już w Fenomenologii ducha:

\begin{abstract}
Jednak istotne jest, że absolutna istota [będąca przedmiotem] wiary nie jest abstrakcyjna istotą znajdującą się po tamtej stronie świadomości wierzącej, lecz jest ona duchem gminy, jednością abstrakcyjnej istoty i samowiedzy. W tym, że istotą absolutna jest ten duch gminy, istotnym momentem jest działanie gminy; duch ten jest istotą absolutna tylko dirieki wytwarzaniu przez śniadomość; — albo raczej nie [jest nia] bez tego [momentu], że jest wytwarzany przez świadomość; bo aczkolwiek wytwarzanie jest czymś istotnym, to istotne jest również to, że nie jest ono jedyna podstawą istoty, lecz tylko jej momentem. Istota istnieje zarazem sama w sobie i dla siebie (Hegel 2002, $355)$.
\end{abstract}

Duch obiektywny - wspólnota Ducha Świętego - nie jest żadnym spirytualistycznym bytem, wyższa istota spoza rzeczywistości, jest za to przedmiotem (przedmiotowością społeczna materialna infrastrukturą świata) założonym przez świadomość podmiotowa jako ,istniejąca

37 Wirtualny duch (substancja, wielki Inny) istniejący tylko poprzez podmiotową wiarę w jego istnienie to jeden z ulubionych spekulatywnych motywów u Žižka: „Transcendencja wielkiego Innego jako substancjalności W-sobie - czyli porządku »ducha obiektywnego« istniejącego niezależnie od podmiotowej aktywności - jest w zasadzie rodzajem koniecznego złudzenia perspektywy; jest forma, pod pozorem której podmiot (nie)dostrzega [(mis)perceive] swojej niezdolności do uchwycenia tego W-sobie rzeczywistego innego, którego prawdziwe intencje pozostaja nieprzeniknione. W tym sensie status duchowej Substancji jest wirtualny: tym, co jest wirtualne w wielkim Innym, jest jego W-sobie, za sprawą którego wielki Inny nie może zostać zredukowany do intencji, znaczeń, stanów fizycznych itd. faktycznie istniejących indywiduów [...]. W tym sensie każda ludzka wspólnota jest »wirtualna«: ufundowana na regułach, wartościach itd., których ważność jest z definicji założona, a nigdy ostatecznie nie dowiedziiona - status wielkiego Innego jest zawsze pozorny" (Žižek 1996, 139-140). Tak Žižek odczytuje twierdzenie Hegla, że nie można oszukać większości w społeczeństwie, tzn. nawet jeśli jakaś idea była ustanowiona przez cyniczny aparat władzy jako czysto instrumentalne, ideologiczne oszustwo, to w momencie, gdy większość zaakceptuje to pojęcie jako fundament swojego społecznego istnienia, przestaje być ono kłamstwem, a staje się substancjalną prawdą wspólnoty. To wspólnota uznaje czy coś jest jej substancjalną prawda, czy zwykłym oszustwem, ponieważ nie ma innego fundamentu niż ten ustanowiony przez działające podmioty. W ten paradoksalny sposób należałoby odczytywać dictum nowoczesnej propagandy wyrażone przez Goebbelsa, że „kłamstwo powtarzane tysiąc razy staje się prawdą”. 
zarazem sama w sobie i dla siebie". Oznacza to, że duch jest heteronomicznie wytworzony przez wolną podmiotowość jako autonomiczny i samorzutny - nadający dopiero określenie świadomości, która go założyła jako swoją przesłankę. Skutek retroaktywnie wytwarza swoja przyczynę. Na tym zapętlonym ruchu logicznym opiera się kluczowy dla Žižkowskiej lektury Hegla $^{38}$ paradoksalny gest upodmiotowienia-ustanowienia polegający na czysto formalnym akcie pojmowania czegoś pozornie niezależnego, obcego i zewnętrznego (np. ducha, sprawy społecznej czy idei, dla której się poświęcamy ${ }^{39}$ ) jako rzeczywistego rezultatu naszego ustanowienia (Besetzung) (por. Žižek 2013, 59). Paradoks ten Hegel ukazuje na przykładzie relacji między wiedzą a prawdą (podmiotowym ustanawianiem prawdy jako niezależnej od tegoż ustanawiania): „pojęcie mytwarza prawdę - jest to podmiotowa wolność - uznaje jednak zarazem tę treść za coś, co nie jest wytworzone, za prawdę, która istnieje sama w sobie i dla siebie" (Hegel 2006b, 360).

Podmioty, aby ustanowić wspólnotę (gminę), muszą wierzyć w jej obiektywność, sensowność, słowem w to, że jest „prawdą istniejąca w sobie i dla siebie”: ona zaś potrzebuje zewnętrznego spoiwa (aby była zdolna - stwarzając ogólne wartości, reguły i zasady - do neutralizowania napięć i antagonizmów wytwarzających się pomiędzy skonfliktowanymi indywiduami), które trzeba jej dopiero stworzyć jako zewnętrzne. Tak brzmi ostatecznie lekcja udzielana przez uśmierconego Boga - wszelkie byty są wirtualne, niestabilne i nieumocowane, a jedyna, minimalna gwarancja ich istnienia jest nieskończona praca miłości do bólu skończonych podmiotów ${ }^{40}$. Pamiętajmy, że tym umierającym Bogiem jest Chrystus król żebraków - wyrzutek porzucony nawet przez swoich uczniów, który zostaje tym samym zredukowany do ekskrementalnej resztki, społecznego poziomu zero. Dlatego właśnie może on być fundamentem dla nowej prawdziwie wspólnotowej wspólnoty wiernych, która działa wedle logiki „dziś niczym, jutro wszystkim”. Ten kolektyw, którego nowoczesną wersją będą

38 W tym miejscu można zastanowić się, czy dekonstrukcjonistka Malabou i lacanista Žižek na poziomie treści nie mówiliby tego samego (u Hegla na krzyżu umiera sam Bóg transcendentny i człowiek pozostaje całkowicie sam w tym przygodnym i nienaprawialnym świecie), ale na poziomie formy już nie (Malabou, nie mogąc się w pełni pogodzić z taką kondycją świata, poszukiwałaby jakiejś mesjańskiej przyszłości w Heglu, natomiast Žižek nakazywałby raczej przyjać i uznać za Heglem ten upadły świat bez Boga z całym jego inwentarzem, zamiast wypatrywać „gwiazdy zbawienia”).

$39 \mathrm{~W}$ tym sensie, z perspektywy heglo-lacanowskiej cała tajemnica poświęcenia nie tkwi w jego przedmiocie, który jest wtórny i przygodnie ustanowiony, tylko w samym akcie poświęcania, który jest autoteliczny poświęcając swoje życie dla sprawy (religijnej, politycznej, etycznej itd.), w istocie „poświęcamy poświęcenie”.

40 Można już zatem zarysować trzy podstawowe stanowiska polityczne związane z interpretacją religii u Hegla: gnostycką prawicę (Nowicki), mesjańskie centrum (Malabou) i materialistyczną lewicę (Žižek). Nieco upraszczając: dla partii gnostyków ten świat jest upadły, a filozofia Hegla (wiedza absolutna) stanowi poznanie (gnosis) zapewniające dostęp do wyższej realności - ucieczka z polityki do spekulacji; dla partii mesjanistów rzeczywistość jest pękniętą immanencją, która wyczekuje w otwarciu na to, co nadejdzie, spełnienie się czasu - liberalno-demokratyczna polityka „mesjańskiej ręki” sprawiedliwości; wreszcie dla partii materialistów wykolejony i wewnętrzne rozbity świat to jedyna rzeczywistość, jaką mamy, w której przed pełzająca apokalipsą może uchronić tylko radykalnie egalitarna komunistyczna wspólnota - polityka rewolucyjnej miłości. 
wszystkie emancypacyjne i rewolucyjne ruchy polityczne, realizuje materialistyczną formę społecznej organizacji. Materializm nie jest normatywnym wzorcem narzucanym z zewnątrz przez nauczyciela-wielkiego Innego (jak w stalinowskiej partii), ale rezultatem wzajemnej praktyki członków wspólnoty, która uśmierciła już swojego nauczyciela, a raczej zaakceptowała jego nieistnienie.

Reasumując, analogiczna jak w Duchu świętym retroaktywna dialektyka przyczyny i skutku pracuje w relacji pomiędzy dwoma końcami: niekończący koniec (nieustający ruch bez końca) wytwarza swój cel, koniec kończący (jako regulatywy moment swojego ruchu założony i nigdy nieosiagnięty) jako coś obiektywnego i autonomicznego, tj. jako realny koniec, który zakończy niekończącą się pracę. Dlatego figurą ich wzajemnie zmediatyzowanej relacji może być nieskończony koniec (nieskończoność i koniec są nieredukowalne do siebie i jednocześnie nierozłącznie uwarunkowane). Mówiąc krótko, dialektyczne kończenie bez końca ma swoją przyczynę w nie-dialektycznym końcu końców, który jest jako kończący (cel) założony przez to, co nieskończone (ruch). Podobnie koniec Boga - śmierć na krzyżu - jest zapośredniczony z nieskończoną praca wspólnoty wiernych jako ze swoim wewnętrznym momentem. Wreszcie, wyobrażeniowa forma religijna zostaje zniesiona w myśleniu filozoficznym, przez które to myślenie zostaje założona jako jego podstawa: religijne Andacht jako nie-spekulatywny, puszczony wolno moment umożliwiający i napędzający spekulatywną maszynę Aufhebung.

Religia stanowi centrum Heglowskiej spekulacji, będąc w całej swojej dwuznaczności spekulatonową anomalia religii jako formy wyobrażenia - zatrzymaniem i spetryfikowaniem w sobie, mglistym odblaskiem odroczonej i resztkowej wieczności w strukturze czasowego procesu - i spekulatywnej treści religii, tj. Boga będącego w permanentnym ruchu samo-znoszenia i samo-wyobcowania, który powraca do siebie w intersubiektywnej wspólnocie, w Duchu Świętym. Jego historyczną postacią jest „duch obiektywny" - rewolucyjna wspólnota czynów miłości, pozbawiona zewnętrznych gwarancji, bo „[g]warancji takich historia nigdy i w żadnej rewolucji nie dawała i absolutnie dać nie może" (Lenin 1953, 184). 


\section{Wykaz literatury}

Ewangelia Tomasza. 1986. Tłum. Wincenty Myszor. W Apokryfy Nowego Testamentu t. I, red. Marek Starowiejski. Lublin: Towarzystwo Naukowe KUL.

Gramsci, Antonio. 1991. Zeszyty filozoficzne. Tłum. Barbara Sieroszewska i Joanna Szymanowska. Warszawa: PWN.

Hegel, Georg Wilhelm Friedrich. 1990. Encyklopedia nauk filozoficznych. Tłum. Światosław Florian Nowicki. Warszawa: PWN.

Hegel, Georg Wilhelm Friedrich. 1995. Vorlesungen über die Philosophie der Religion. Band 3: Die vollendete Religion. Hamburg: Felix Meiner Verlag.

Hegel, Georg Wilhelm Friedrich. 2002. Fenomenologia ducha. Tłum. Światosław Florian Nowicki. Warszawa: Fundacja Aletheia.

Hegel, Georg Wilhelm Friedrich. 2006a. Wykłady z filozofii religii, t. I. Tłum. Światosław Florian Nowicki. Warszawa: PWN.

Hegel, Georg Wilhelm Friedrich. 2006b. Wykłady z filozofii religii, t. II. Tłum. Światosław Florian Nowicki. Warszawa: PWN.

Hegel, Georg Wilhelm Friedrich. 2011a. Nauka logiki, t. I. Tłum. Adam Landman. Warszawa: PWN.

Hegel, Georg Wilhelm Friedrich. 2011b. Nauka logiki, t. II. Tłum. Adam Landman. Warszawa: PWN.

Hegel, Georg Wilhelm Friedrich. 2013. Wykłady z bistorii filozofii, t. I. Tłum. Światosław Florian Nowicki. Warszawa: PWN.

Hegel, Georg Wilhelm Friedrich. 1969. Zasady filozofii prawa. Tłum. Adam Landman. Warszawa: PWN.

Lenin, Włodzimierz. 1953. „List do towarzyszy”. W Lenin, Włodzimierz. Drieła, t. 26. Warszawa: Książka i Wiedza: 183-202.

Löwith Karl. 2001. Od Hegla do Nietæschego: Rewolucyjny przełom w myśli XIX wieku. Tłum. Stanisław Gromadzki. Warszawa: Wydawnictwo KR.

Lukács, György. 1980. Młody Hegel: O powiqzaniach dialektyki z ekonomiq. Tłum. Marek Jerzy Siemek. Warszawa: PWN.

Magee, Glenn Alexander. 2001. Hegel and the Hermetic Tradition. Ithaca-London: Cornell University Press.

Malabou, Catherine. 2006. The Future of Hegel: Plasticity, Temporality, Dialectics. Tłum. Lisabeth During. Oxfordshire-New York: Routledge.

Malabou, Catherine. 2017. Ontologia przypadtości: Esej o destrukcyjnej plastyczności. Tłum. Piotr Skalski. Warszawa: Fundacja Augusta hr. Cieszkowskiego.

Mikołaj z Kuzy. 1997. O oświeconej niewiedsy. Tłum. Ireneusz Kania. Kraków: SIW Znak.

Mistrz Eckhart. 2013. Dizieła wşystkie, t. I. Tłum. Wiesław Szymona OP. Poznań: Wydawnictwo W drodze.

Nancy, Jean-Luc. 2002. Hegel: The Restlessness Of The Negative. Tłum. Jason Smith i Steven Miller. Minneapolis: University of Minnesota Press.

Pinkard ,Terry. 2000. Hegel: A Biography. Cambridge: Cambridge University Press.

Pańków, Marcin. 2012. „O ontologicznej formie intersubiektywności: Kilka ustaleń w oparciu o Schillera i Hegla oraz rzut oka na dziś". W Intersubiektywność, red. Piotr Makowski. Kraków: Universitas: 41-64.

Sosnowski, Maciej Adam. 2013. „»...przypadkowość, arbitralność, bezład...«: O pojednaniu religii i filozofii w myśli G. W. F. Hegla". W Deus otiosus: Nowoczesność w perspektywie postsekularnej, red. Agata Bielik-Robson i Maciej Adam Sosnowski. Warszawa: Wydawnictwo Krytyki Politycznej: 91-119. 
Sosnowski, Maciej Adam. 2017. „Niestrawności: O dialektyce i wymiotowaniu”. Præeglad Filozoficzno-Literacki 1: 325-336.

Werner Florian. 2014. Ciemna materia: Historia gómna. Tłum. Elżbieta Kalinowska. Wrocław: Wydawnictwo Czarne.

Zabala, Santiago. 2010. „Wprowadzenie: Religia poza teizmem i ateizmem”. W Rorty, Richard i Gianni Vattimo. Praysz̧łość religii, red. Santiago Zabala. Tłum. Stanisław Królak. Kraków: Wydawnictwo UJ: 9-36.

Žižek, Slavoj. 1996. The Indivisible Remainder: An Essay on Schelling and Related Matters. LondonNew York: Verso.

Žižek, Slavoj. 2001. Wžniosty obiekt ideologii. Tłum. Joanna Bator i Paweł Dybel. Wrocław: Wydawnictwo UWr.

Žižek, Slavoj. 2006. Kukła i karzeł: Perwersyjny rdz̨eń chrześcijaństwa. Tłum. M. Kropiwnicki. Bydgoszcz-Warszawa-Wrocław: Oficyna Wydawnicza Branta.

Žižek, Slavoj. 2009. "The Fear of Four Words: A Modest Plea for the Hegelian Reading of Christianity”. W Žižek, Slavoj i John Milbank. The Monstrosity of Christ: Paradox or Dialectic?, red. Creston Davis. Cambridge, MA-London: The MIT Press.

Žižek, Slavoj. 2012. Less Than Nothing: Hegel and The Shadow of Dialectical Materialism. LondonNew York: Verso.

Žižek, Slavoj. 2013. Metastazy rozkoszyy: Sześć esejón o kobietach i prayczynowości. Tłum. Marek Jastrzębiec-Mosakowski. Warszawa: Wydawnictwo Krytyki Politycznej. 
Bartosz Wójcik - filozof, materialista dialektyczny, asystent naukowy w Instytucie Nauk Politycznych PAN. Przygotowuje doktorat poświęcony filozofii społecznej Hegla. Członek kolektywu redakcyjnego Praktyka Teoretyczna.

\section{DANE ADRESOWE:}

Instytut Nauk Politycznych PAN

ul. Polna 18/20

00-625 Warszawa

EMAIL: bartosz.k.wojcik@gmail.com

CYTOWANIE: Wójcik, Bartosz. 2018. „Koniec religii, śmierć Boga i przygodna wspólnota: Hegel, Malabou, Žižek.“ Praktyka Teoretycznna 2(28): 53-84.

DOI: $10.14746 /$ prt.2018.2.3

FINANSOWANIE: Praca naukowa finansowana ze środków Narodowego Centrum Nauki realizowana w ramach projektu "Filozofia negatywności Hegla i Žižka". Projekt nr 2016/21/N/HS1/03514.

AUTHOR: Bartosz Wójcik

TITLE: The End of Religion, the Death of God and the Contingent Community: Hegel, Malabou, Žižek.

ABSTRACT: The article is an interpretation of the concept of the end of religion in Hegel's philosophy, based on the analysis of three issues:

1. The relationship between religious imagination and speculative philosophy - i.e. the idea of the sublation of religion into philosophy.

2. The Hegelian understanding of Christianity (presented in Encyclopaedia of the Philosophical Sciences and Lectures on the Philosophy of Religion) focused on the idea of incarnation as kenosis, which is interpreted by Catherine Malabou's theory.

3. The idea of the death of Christ as the death of God himself that constitutes the authentic core of Christianity - as Slavoj Žižek has claimed.

This interpretation leads to the conclusion: the outcome of this death is God qua Holy Spirit, whose historical embodiment is "objective spirit" - revolutionary community of the acts of love.

KEYWORDS: Hegel, dialectic, religion, Malabou, Žižek, Christianity, God, community. 